\title{
Seasonal and Spatial Variation in the Location and Reactivity of a Nitrate-Contaminated Groundwater Discharge Zone in a Lakebed
}

RL Smith

DA Repert

DL Stoliker

DB Kent

BK Song

Virginia Institute of Marine Science

See next page for additional authors

Follow this and additional works at: https://scholarworks.wm.edu/vimsarticles

Part of the Biogeochemistry Commons

\section{Recommended Citation}

Smith, RL; Repert, DA; Stoliker, DL; Kent, DB; Song, BK; and al, et, "Seasonal and Spatial Variation in the Location and Reactivity of a Nitrate-Contaminated Groundwater Discharge Zone in a Lakebed" (2019). VIMS Articles. 1678.

https://scholarworks.wm.edu/vimsarticles/1678 
Authors

RL Smith, DA Repert, DL Stoliker, DB Kent, BK Song, and et al 


\section{JGR Biogeosciences}

\author{
RESEARCH ARTICLE \\ 10.1029/2018JG004635 \\ Key Points: \\ - Changing lake levels control the \\ location of \\ wastewater-contaminated \\ groundwater discharging to a \\ freshwater glacial kettle lake \\ - Lakebed pore water geochemistry at \\ the discharge location reflects $\mathrm{N}$ \\ cycle processes in upgradient \\ groundwater \\ - Short pore water residence time in \\ more carbon-rich surficial \\ sediments limits nitrate removal \\ prior to discharge into the lake
}

Supporting Information:

- Supporting Information S1

Correspondence to:

R. L. Smith and S. P. Hyun,

rlsmith@usgs.gov;

sphyun@kigam.re.kr

Citation:

Smith, R. L., Repert, D. A., Stoliker, D. L., Kent, D. B., Song, B., LeBlanc, D. R., et al. (2019). Seasonal and spatial variation in the location and reactivity of a nitrate-contaminated groundwater discharge zone in a lakebed. Journal of Geophysical Research: Biogeosciences, 124, 2186-2207. https://doi.org/ 10.1029/2018JG004635

Received 4 JUN 2018 Accepted 18 JUN 2019

Accepted article online 24 JUN 2019

Published online 19 JUL 2019

Author Contributions:

Conceptualization: Richard L. Smith, Douglas B. Kent, Bongkeun Song, Denis R. LeBlanc, J. K. Böhlke, Sung Pil Hyun

Data curation: Deborah A. Repert, Deborah L. Stoliker, Douglas B. Kent, Timothy D. McCobb, J. K. Böhlke Formal analysis: Richard L. Smith, Douglas B. Kent, Bongkeun Song Funding acquisition: Denis $\mathrm{R}$. LeBlanc, Sung Pil Hyun Methodology: Richard L. Smith, Deborah A. Repert, Deborah L. (continued)

(C)2019. American Geophysical Union. All Rights Reserved.

This article has been contributed to by US Government employees and their work is in the public domain in the USA.

\section{Seasonal and Spatial Variation in the Location and Reactivity of a Nitrate-Contaminated Groundwater Discharge Zone in a Lakebed}

\author{
Richard L. Smith ${ }^{1}$ (D), Deborah A. Repert ${ }^{1}$ (D), Deborah L. Stoliker ${ }^{2}$ (D), Douglas B. Kent ${ }^{2}$ (D), \\ Bongkeun Song 3 , Denis R. LeBlanc ${ }^{4}$ (D) Timothy D. McCobb ${ }^{4}$ (D) J. K. Böhlke ${ }^{5}$ (D), \\ Sung Pil Hyun ${ }^{6}$, and Hee Sun Moon ${ }^{6}$
}

${ }^{1}$ U.S. Geological Survey, Boulder, CO, USA, ${ }^{2}$ U.S. Geological Survey, Menlo Park, CA, USA, ${ }^{3}$ Virginia Institute of Marine Science, Gloucester Point, VA, USA, ${ }^{4}$ U.S. Geological Survey, Northborough, MA, USA, ${ }^{5}$ U.S. Geological Survey, Reston, VA, USA, ${ }^{6}$ Korea Institute of Geoscience and Mineral Resources, Daejeon, South Korea

\begin{abstract}
Groundwater discharge delivering anthropogenic $\mathrm{N}$ from surrounding watersheds can impact lake nutrient budgets. However, upgradient groundwater processes and changing dynamics in $\mathrm{N}$ biogeochemistry at the groundwater-lake interface are complex. In this study, seasonal water-level variations in a groundwater flow-through lake altered discharge patterns of a wastewater-derived groundwater contaminant plume, thereby affecting biogeochemical processes controlling $\mathrm{N}$ transport. Pore water collected $15 \mathrm{~cm}$ under the lakebed along transects perpendicular to shore varied from oxic to anoxic with increasing nitrate concentrations $(10-75 \mu \mathrm{M})$ and corresponding gradients in nitrite and nitrous oxide. Pore water depth profiles of nitrate concentrations and stable isotopic compositions largely reflected upgradient groundwater $\mathrm{N}$ sources and $\mathrm{N}$ cycle processes, with minor additional nitrate reduction in the near-surface lakebed sediments. Potential denitrification rates determined in laboratory microcosms were 10-100 times higher in near-surface sediments $(0-5 \mathrm{~cm})$ than in deeper sediments $(5-30 \mathrm{~cm})$ and were correlated with sediment carbon content and abundance of denitrification genes (nirS, nosZI, and nosZII). Potential anammox-driven $\mathrm{N}_{2}$ production was detectable in deeper anoxic sediments. Injection of bromide and nitrite in the lake sediments showed that the highest net nitrite consumption rates were within the top $10 \mathrm{~cm}$. However, short transit times owing to rapid upward pore water velocities $\left(4-5 \mathrm{~cm} \mathrm{hr}^{-1}\right)$ limited removal of the contaminant nitrate transiting through the sediments. Results demonstrate that local hydrologic and biogeochemical processes at the point of discharge affect the distribution and discharge rate of $\mathrm{N}$ through lakebed sediments, but processes in the upgradient groundwater can be more important for affecting $\mathrm{N}$ speciation and concentration.
\end{abstract}

Plain Language Summary This study examined what happens to nitrate, a primary wastewater contaminant in groundwater, as contaminated groundwater flows upward into the bottom of a freshwater lake. Nitrate can serve as a fertilizer within the lake, causing a decrease in the quality of the lake water and potentially contributing to the growth of harmful algae. Groundwater nitrate discharged into the lake primarily near the lake shore, but the location of the discharge moved as the lake level rose and fell. Only a fraction of the nitrate passing through the sediments was removed before the groundwater exited into the lake because rapid flow through the lake-bottom sediments limited the time for biogeochemical nitrate removal to occur.

\section{Introduction}

Nutrient loading to lakes and the resulting potential for algal blooms and eutrophication have substantial implications for human health and the health of lacustrine ecosystems. Inorganic nitrogen $(\mathrm{N})$, primarily in the form of nitrate $\left(\mathrm{NO}_{3}{ }^{-}\right)$, is a common groundwater contaminant and is often found in groundwater discharging to lakes and other surface water bodies (Kidmose et al., 2015; Lewandowski et al., 2015; Nakayama \& Watanabe, 2008; Robinson, 2015). In groundwater, $\mathrm{NO}_{3}{ }^{-}$primarily serves as an electron acceptor for oxidation processes once dissolved oxygen $\left(\mathrm{O}_{2}\right)$ levels have been depleted (Smith \& Harris, 
Stoliker, Douglas B. Kent, Bongkeun Song, Denis R. LeBlanc, Timothy D. McCobb, J. K. Böhlke, Sung Pil Hyun, Hee Sun Moon

Writing - original draft: Richard L. Smith

Writing - review \& editing: Richard L. Smith, Deborah A. Repert, Deborah L. Stoliker, Douglas B. Kent, Bongkeun Song, Denis R. LeBlanc, Timothy D. McCobb, J. K. Böhlke, Sung Pil Hyun, Hee Sun Moon
2007), whereas its role in assimilation to support biomass growth is usually relatively minor. In lakes, the situation is reversed; $\mathrm{NO}_{3}{ }^{-}$is primarily a nutrient, where it is assimilated by plants and algae for growth, and $\mathrm{NO}_{3}{ }^{-}$dissimilatory processes are generally limited relative to assimilation (Wetzel, 1975). However, much remains to be learned about the fate and transport of $\mathrm{NO}_{3}{ }^{-}$at the groundwater-lake interface. What is the effect of the physical and hydrologic transition on contaminant $\mathrm{NO}_{3}{ }^{-}$as it discharges into a lake? Do the lake sediments, which are generally more carbon (C)-rich than aquifer sediments, alter the amount and the speciation of the $\mathrm{NO}_{3}{ }^{-}$just prior to discharge?

Lakes such as kettle ponds and prairie potholes of the glaciated northern U.S. are commonly connected hydraulically to surrounding shallow water table aquifers. Many of these lakes are groundwater flow-through lakes where groundwater discharges into the lake on the upgradient side and lake water seeps back into the groundwater on the downgradient side of the lake (Winter, 1986). Although spatial distributions and rates of groundwater/surface water exchange can be complex, the exchanges generally are focused in nearshore areas of a lake (McBride \& Pfannkuch, 1975). Many lakes, such as those located in glacial drift, have little or no connection to streams and have groundwater-dominated water budgets (Wetzel, 1975). The natural habitats of these lakes may be particularly sensitive to inputs of contaminated groundwater. Groundwater discharge into a lake can be affected by many factors that vary spatially and temporally, including aquifer thickness, composition, and heterogeneity; regional water table gradients; seasonal and long-term variations in precipitation and evapotranspiration that affect aquifer recharge; watershed topography; and lake depth, wave and wind action, and the type of littoral zone vegetation (Keery et al., 2007; Lewandowski et al., 2015; Pfannkuch \& Winter, 1984; Rosenberry et al., 2000; Rosenberry et al., 2013; Winter et al., 1998). Because the shallow zones of a lake receive most of the groundwater discharge, the nearshore sediments are important locations where biogeochemical processes in the sediments may transform, store, or potentially remove groundwater contaminants, such as $\mathrm{NO}_{3}{ }^{-}$, before they reach the lake water (Stoliker et al., 2016). The extent to which this happens and how the processes respond to and are affected by discharge variability and heterogeneity are largely unknown.

Dissimilatory nitrogen transformations that can affect $\mathrm{NO}_{3}{ }^{-}$at the groundwater-lake interface include nitrification, denitrification, anaerobic ammonium $\left(\mathrm{NH}_{4}{ }^{+}\right)$oxidation (anammox), and dissimilatory nitrate reduction to ammonium (DNRA). Nitrification is an aerobic process that produces $\mathrm{NO}_{3}{ }^{-}$from the oxidation of $\mathrm{NH}_{4}{ }^{+}$or organic $\mathrm{N}$. The other processes are anoxic and compete for nitrogen oxides as electron acceptors. Denitrification and anammox remove fixed $\mathrm{N}$ by reducing $\mathrm{NO}_{3}{ }^{-}$or nitrite $\left(\mathrm{NO}_{2}{ }^{-}\right)$and producing nitrogen gas $\left(\mathrm{N}_{2}\right)$, while DNRA alters the mobility of the fixed $\mathrm{N}$, without removing it, by reducing $\mathrm{NO}_{3}{ }^{-}$to $\mathrm{NH}_{4}{ }^{+}$. Nitrification and denitrification have been widely studied in rivers and streams as important mediators of N transport (Böhlke et al., 2009; Duff et al., 2008; Groffman et al., 2005; Hinkle et al., 2001; Mulholland et al., 2009; Peterson et al., 2001), and all of these processes have been found in groundwater and lake sediments (Hampel et al., 2018; Li et al., 2017; Miller \& Smith, 2009; Rissanen et al., 2013; Rysgaard et al., 1993; Salk et al., 2018; Smith et al., 2015; Smith \& Duff, 1988; Smith et al., 1991b; Stoliker et al., 2016; Washbourne et al., 2011). Abiotic reactions, such as the oxidation of iron $\left(\mathrm{Fe}^{+2}\right)$ by $\mathrm{NO}_{2}{ }^{-}$producing nitrous oxide $\left(\mathrm{N}_{2} \mathrm{O}\right)$, can also contribute to $\mathrm{N}$-species cycling (Klueglein et al., 2014; Klueglein \& Kappler, 2013). Interactions among the $\mathrm{N}$ cycle processes can affect the ultimate amount and speciation of $\mathrm{N}$ transported across the groundwater/surface water interface and the extent to which $\mathrm{NO}_{3}{ }^{-}$-containing groundwater will contribute to whole-lake $\mathrm{N}$ budgets.

Several redox species of $\mathrm{N}$ can be readily quantified in sediment pore water: $\mathrm{N}(\mathrm{V})\left(\mathrm{NO}_{3}{ }^{-}\right), \mathrm{N}$ (III) $\left(\mathrm{NO}_{2}{ }^{-}\right), \mathrm{N}(\mathrm{I})\left(\mathrm{N}_{2} \mathrm{O}\right)$, and $\mathrm{N}(-\mathrm{III})\left(\mathrm{NH}_{3}, \mathrm{NH}_{4}{ }^{+}\right.$, and organic $\left.\mathrm{N}\right)$. Changes in the $\mathrm{N}$ and $\mathrm{O}$ isotopic composition of these species provide insight into the controls on redox reactions (Buchwald \& Casciotti, 2013; Casciotti, 2016; Granger et al., 2008). Genes encoding enzymes that catalyze various $\mathrm{N}$ cycle redox reactions can now be identified and quantified, which can indicate the genetic potential of various microbial activities (see review of Damashek \& Francis, 2018). Abundance of denitrification genes such as $\mathrm{NO}_{2}{ }^{-}$reductase (nirS) and $\mathrm{N}_{2} \mathrm{O}$ reductase (nosZ) was shown to have a significant positive correlation with potential denitrification rates in river sediments, while no correlation was observed between anammox rates and the genes encoding hydrazine oxidoreductase (hzo; Lisa et al., 2015). A meta-analysis found significant correlation of denitrification activities with both nirS and nos $\mathrm{Z}$ genes, 

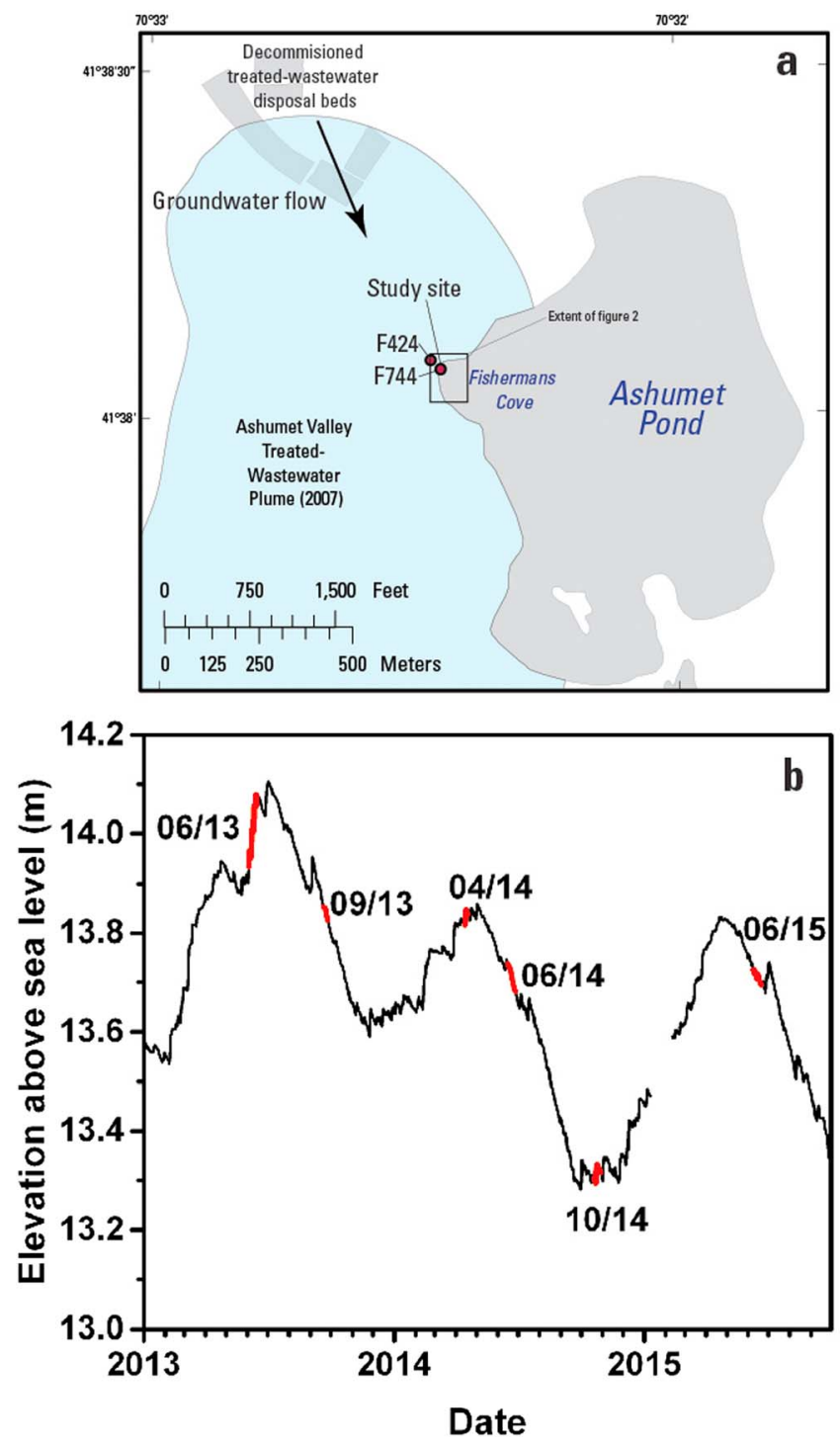

Figure 1. (a) Map of Ashumet Pond and extent of wastewater-contaminated groundwater plume, a portion of which discharges into the lake (Barbaro et al., 2013; LeBlanc, 1984). Sampling locations shown are well sites F424 and F744 and Fishermans Cove in the lake. (b) Daily average water-level elevation of Ashumet Pond from 1 January 2013 to 30 September 2015. Highlighted in red are the periods when field sampling for this study was conducted. but not with their transcripts (an indicator of gene expression), suggesting that gene abundance is a better genetic predictor of denitrification than transcriptional expression (Rocca et al., 2015).

Previously, we presented findings from an investigation of hydrologic controls on $\mathrm{N}$ cycling in sediments in Ashumet Pond-a groundwater flowthrough lake on Cape Cod, Massachusetts-at a single point in time (Stoliker et al., 2016). Functional genes for the N cycling processes-denitrification, anammox, and nitrification-were present in sediments collected from three shallow nearshore areas, where (1) uncontaminated groundwater discharges to the lake; (2) anoxic groundwater with elevated concentrations of $\mathrm{NO}_{3}{ }^{-}$from a well-characterized wastewater source (McCobb et al., 2003; McCobb \& LeBlanc, 2011) discharges to the lake at Fishermans Cove (sic); and (3) lake water recharges the aquifer. Potential activity of $\mathrm{N}$ cycling microbial communities in lakebed sediments was lowest where oxic, uncontaminated groundwater discharges to the lake and highest where lake water enters the sediments, supplying lake-derived labile organic $\mathrm{C}$. In this paper we present a detailed examination of the impact of changes in lake stage (i.e., the elevation of the lake surface) on the $\mathrm{N}$ cycling activity of microbial communities in sediments in a groundwater discharge area at Fishermans Cove. We hypothesized that changes in the lake stage and associated shifts in the shoreline location affect the composition of groundwater flowing through the lakebed sediments at any given location. This results in coincident effects on $\mathrm{N}$ cycling processes, microbial communities, and changes in the flux of $\mathrm{N}$ species into the lake. Specifically, at high lake stages, shallow lake-bed sediments several meters or more from the shoreline accumulate lakederived organic $\mathrm{C}$ and are exposed to $\mathrm{NO}_{3}{ }^{-}$as anoxic groundwater discharges into the lake. As the stage drops, submergence and distance from shore decrease, which may affect the supply to the sediments of lakederived organic $\mathrm{C}$; increase groundwater discharge rates; and change groundwater chemical conditions, including lower $\mathrm{NO}_{3}{ }^{-}$concentrations and higher dissolved $\mathrm{O}_{2}$ concentrations than at higher lake stages. At low stages, sediments may become exposed onshore and in contact with the atmosphere. Subsequent increases in lake stage cause the reverse sequence of events. We document changes in the location of discharge of $\mathrm{NO}_{3}{ }^{-}$contamination and the concomitant changes in microbial communities and the $\mathrm{N}$-processing functions they provide driven by temporal cycles in lake stage. Changes in $\mathrm{N}$-processing functions were examined by determining pore water chemistry, functional gene abundance, and rates of $\mathrm{N}$ cycle processes determined in laboratory experiments and in situ tracer tests.

\section{Methods}

\subsection{Study Site}

The study site is an unconfined sand and gravel aquifer and associated freshwater glacial kettle lake, Ashumet Pond, on western Cape Cod, Massachusetts (Figure 1a) that have been a focal point of more than three decades of study by the U.S. Geological Survey Toxic Substances Hydrology Program of contaminant fate and transport in shallow groundwater in granular aquifers (http://pubs.usgs.gov/fs/2006/3096). Ashumet Pond has an area of about $0.82 \mathrm{~km}^{2}$ and a maximum depth of $26 \mathrm{~m}$ and is a groundwater flowthrough lake, with no surface water outlet and only a minor surface water inlet. The water table aquifer connected hydraulically to Ashumet Pond was contaminated by disposal of treated wastewater onto surface infiltration beds for $>60$ years (LeBlanc, 1984; Repert et al., 2006). A portion of the wastewater contaminant plume discharges into Ashumet Pond in the vicinity of Fishermans Cove (McCobb et al., 2003; Stoliker et al., 
2016), which is about 2-years groundwater travel time downgradient from the infiltration bed location. The lake and the study site location are typical of settings where wastewater plumes from septic systems discharge to surface water environments.

The well-characterized, groundwater contaminant plume at the Cape Cod site is more than $7 \mathrm{~km}$ long, 1.2 $\mathrm{km}$ wide, and $30 \mathrm{~m}$ thick and contains vertical gradients of biogeochemically reactive dissolved constituents, including $\mathrm{O}_{2}, \mathrm{NO}_{3}{ }^{-}, \mathrm{NH}_{4}{ }^{+}$, phosphate $\left(\mathrm{PO}_{4}{ }^{-3}\right), \mathrm{Fe}^{+2}$, manganese $\left(\mathrm{Mn}^{+2}\right)$, dissolved organic carbon (DOC), and dissolved salts (Barbaro et al., 2013; Böhlke et al., 2006; LeBlanc, 1984; McCobb et al., 2003; Repert et al., 2006; Smith, Howes, et al., 1991; Stoliker et al., 2016). The plume is in a sand and gravel water table aquifer whose physical and hydrologic characteristics have been described previously (Barber et al., 1992; Hess et al., 1992; Kent \& Fox, 2004; LeBlanc et al., 1991). The central core of the plume is anoxic, though as the wastewater-contaminated groundwater moves downgradient, the plume becomes overlain by a zone of uncontaminated, oxic groundwater. Nitrate, $\mathrm{NH}_{4}{ }^{+}$, and $\mathrm{PO}_{4}{ }^{-3}$ are wastewater derived, while other constituents, such as $\mathrm{Fe}^{+2}, \mathrm{Mn}^{+2}$, and arsenic, are naturally occurring, having been mobilized from the aquifer sediments (Kent et al., 1994; Kent \& Fox, 2004). Chemical gradients and locations of biogeochemical reaction zones within the plume have remained relatively stable since monitoring began in 1978, although concentrations of many dissolved constituents have been gradually decreasing with time since the wastewater disposal was discontinued at the site in 1995 (Repert et al., 2006). Denitrification and anammox actively occur within the plume in anoxic or suboxic zones in which $\mathrm{NO}_{3}{ }^{-}$and $\mathrm{NH}_{4}{ }^{+}$are present (Smith et al., 2004; Smith et al., 2015).

Ashumet Pond is a mesotrophic, freshwater lake situated in glacial outwash deposits composed of interbedded coarse sand and gravel. The estimated lake water residence time is 1-2 years (Harvey et al., 2015; LeBlanc et al., 1991; McCobb et al., 2003). The lake, like most kettle lakes on western Cape Cod, has an elevated trophic state owing to nutrient inputs from the wastewater-infiltration beds, septic systems, and fertilizer applications (http://www.capecodcommission.org/index.php?id=171\&maincatid=49). As noted by Stoliker et al. (2016), studying processes that affect nutrient inputs in these lakes is difficult because of the dispersed nature of the inputs. The contaminant plume that is the subject of this study is well characterized, the discharge location within the lake is accessible, the groundwater flow path, direction, and velocity are all well characterized, and the lake stage is continuously monitored with a U. S. Geological Survey (USGS) gaging station, making this an ideal location to investigate the fate and transport of wastewater contaminants across the groundwater-lake interface and the effects of changes in the hydrologic gradient on that transport.

\subsection{Hydrologic Measurements}

Sampling events in Ashumet Pond occurred during six sampling excursions between June 2013 and June 2015, timed to represent seasonal variations in the lake-stage hydrograph (Figure 1b). Groundwater discharge was measured at multiple locations within the shallow-water zone of Fishermans Cove by using a barrel-type seepage meter and manometer (Rosenberry \& LaBaugh, 2008). Sediment temperature was measured at $10 \mathrm{~cm}$ below the sediment surface on a two-dimensional grid by using a portable thermistor probe. When lake water was substantially warmer (summer) or colder (winter) than the regional groundwater temperature, pore water temperature in shallow sediment was used to map areas of substantial groundwater discharge into the lake (McCobb et al., 2018). The Ashumet Pond water level was continuously recorded at the U. S. Geological Survey (USGS) Ashumet Pond gage (https://nwis.waterdata.usgs.gov/ma/ nwis/uv?cb_62614=on\&cb_70969=on\&format=gif_default\&site_no=413758070320501\&period=\&begin_ date=2013-01-01\&end_date=2015-12-31).

\subsection{Water and Sediment Sample Collection}

Groundwater in the vicinity of Ashumet Pond was collected using 15-port multilevel sampling wells (Savoie \& LeBlanc, 1998). Pore water from the lake sediments was collected using 0.64-cm-diameter, stainless steel pushpoint samplers with 4-cm-long screens (MHE Products, East Tawas, MI) driven temporarily into the lake-bottom sediment. Groundwater and sediment pore water were collected using a peristaltic pump and $\mathrm{O}_{2}$-impermeable tubing (Pharmed). Pore water in near-surface sediments $(0-5 \mathrm{~cm}$ below the lake botttom) was collected using a syringe and a pore water surface sampler specifically designed to minimize lake water intrusion during sampling (Figure S1 in the supporting information). Field measurements were made for 


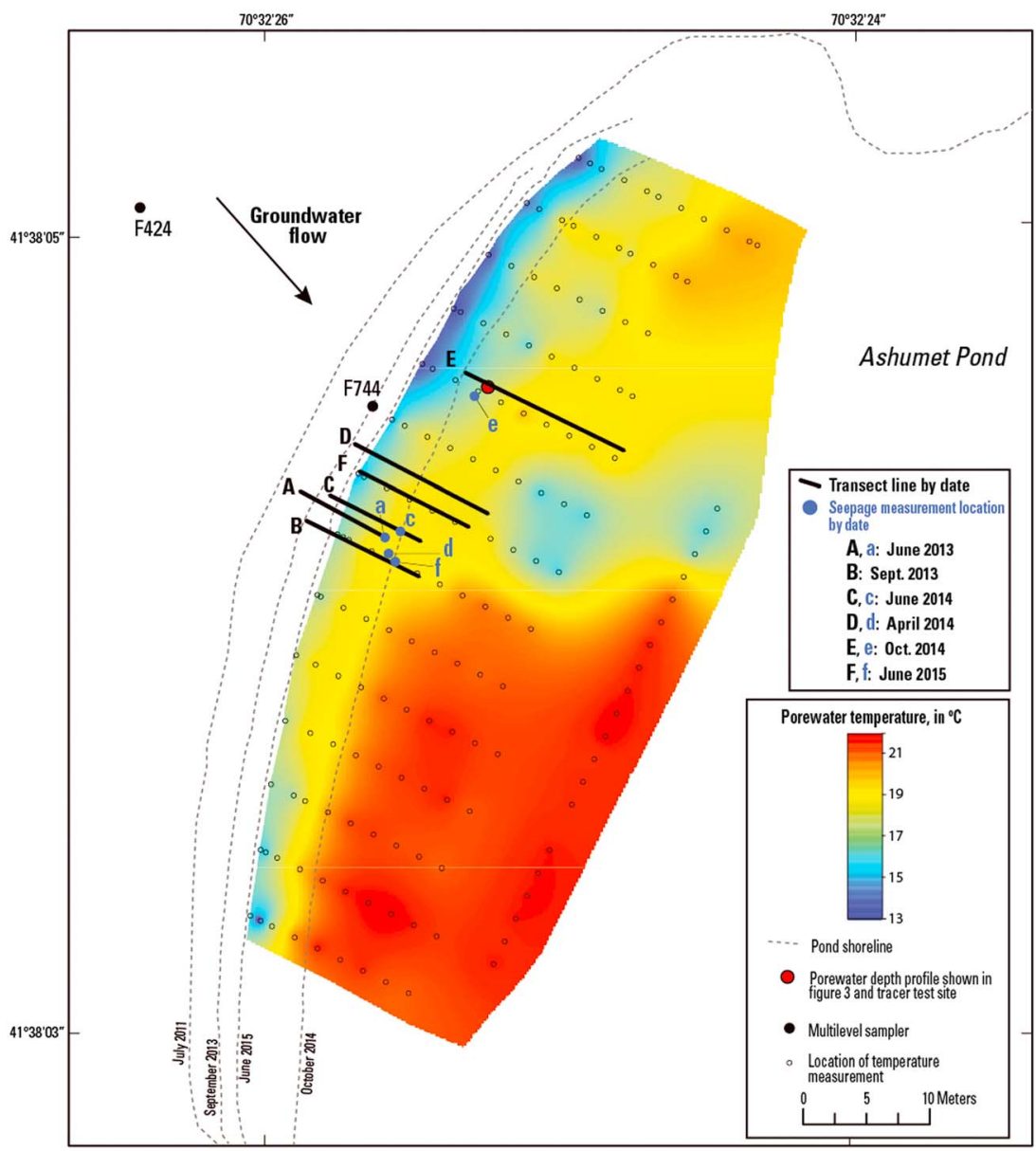

Figure 2. Detailed map of Fishermans Cove showing locations of various sample sites and field measurements in comparison to changing shoreline positions. Colored shading indicates sediment pore water temperatures at a constant depth of $10 \mathrm{~cm}$ in June 2015 , when surface water temperature was $21.8^{\circ} \mathrm{C}$; relatively low temperatures (blue) indicate areas of relatively high groundwater discharge fluxes. Map coordinates in meters relative to North American Datum of 1983. Data in Table S1.

specific conductance, temperature, $\mathrm{pH}, \mathrm{O}_{2}$, and $\mathrm{NO}_{3}{ }^{-}$, and water samples were collected and preserved for analysis of $\mathrm{NO}_{3}{ }^{-}, \mathrm{NO}_{2}{ }^{-}, \mathrm{NH}_{4}{ }^{+}$, DOC, $\mathrm{N}_{2} \mathrm{O}$, and selected inorganic solutes as described elsewhere (Repert et al., 2006; Savoie et al., 2006). Initial sampling for each field excursion was conducted by sampling from temporary pushpoint samplers located along a grid of transects oriented parallel and perpendicular to shore to determine the location of peak $\mathrm{NO}_{3}{ }^{-}$concentrations in the shallow lake-bottom sediments. The field-identified locations were selected for focused sampling, sediment collection, seepage measurements, and tracer tests for each given sampling excursion (see Figure 2).

Lake sediments were collected in Fishermans Cove for genomic and geochemical analyses and microcosm incubations, by driving a steel core barrel fitted with a 5-cm-diameter aluminum core liner to a depth of $30 \mathrm{~cm}$ below the sediment-water interface. Each core was separated into desired depth intervals. Samples from the same depth interval in multiple cores, all collected within about a $1-\mathrm{m}^{2}$ area, were combined to obtain a sufficient quantity of sediment, sieved through a 2-mm-mesh polypropylene screen, and thoroughly mixed. Aliquots of the sieved sediment were frozen on dry ice and shipped to Gloucester Point, VA, for molecular analysis. The remainder of the sieved sediment was transferred to glass canning jars that had been baked at $500{ }^{\circ} \mathrm{C}$. The jars were capped, flushed with ultrahigh-purity helium (He), and shipped on ice for next-day delivery to USGS in Boulder, $\mathrm{CO}$, and Virginia Institute of Marine Science (VIMS) in Gloucester Point, VA. 


\subsection{Microbial Process Assessment}

\subsubsection{DNA Extraction and nosZ, nirS, and hzo Gene Quantification}

Genomic DNA was extracted from $0.5 \mathrm{~g}$ of the lake sediment collected in June 2014 and 2015 by using MO BIO Powersoil extraction kits (MO BIO Laboratories, Inc., Carlsbad, CA) following the manufacturer's protocol. Quantitative polymerase chain reaction (PCR) assays of the genes targeting $\mathrm{N}_{2} \mathrm{O}$ reductase (nos $Z \mathrm{I}$ and nos $Z \mathrm{II})$ and $\mathrm{NO}_{2}{ }^{-}$reductase (nirS) in denitrifying bacteria and hydrazine oxidoreductase (hzo) in anammox bacteria were conducted as previously described (Jones et al., 2013; Lisa et al., 2015).

\subsubsection{Sediment Incubations}

Laboratory microcosm incubations were conducted with slurried lake sediments at $15{ }^{\circ} \mathrm{C}$ to assess rates of four processes-denitrification, net $\mathrm{NO}_{3}{ }^{-}$consumption, anammox, and nitrification-as previously described (Repert et al., 2014; Smith \& Duff, 1988; Stoliker et al., 2016). Rates are considered to be potential rates, not actual in situ rates, but serve as the basis for spatial and temporal sample comparison. All incubations were initiated immediately upon arrival of freshly collected, sieved sediment at the laboratory. Sediments were slurried with groundwater collected from upgradient well F424 (Figure 1a and Table S4). The four process rates were assessed by the following: (1) Denitrification rates were measured using the acetylene $\left(\mathrm{C}_{2} \mathrm{H}_{2}\right)$ block technique (Yoshinari \& Knowles, 1976) to measure $\mathrm{N}_{2} \mathrm{O}$ accumulation with time in the headspace of triplicate, anoxic $60-\mathrm{ml}$ serum bottles containing $30 \mathrm{~g}$ of wet sediment, and $30 \mathrm{ml}$ of groundwater. Concentrated, anoxic solutions of substrates $\left(\mathrm{NaNO}_{3}, 100 \mu \mathrm{M} ; \pm \mathrm{NaC}_{2} \mathrm{H}_{3} \mathrm{O}_{2}, 100 \mu \mathrm{M}\right.$; final concentrations) were added at $t=0 \mathrm{hr}$, the bottles were mixed with end over end rotation, and headspace samples were removed at multiple time points ( $n=6$ to 8 ) and assayed for $\mathrm{N}_{2} \mathrm{O}$ concentration during short-term incubation periods ( $0-24 \mathrm{hr}$ ). Results from the $\mathrm{C}_{2} \mathrm{H}_{2}$ block method were previously shown to be similar to rates of ${ }^{15} \mathrm{~N}_{2}$ production measured using ${ }^{15} \mathrm{NO}_{3}{ }^{-}$(Stoliker et al., 2016). (2) Identical, larger-volume incubations (60 g $+60 \mathrm{ml}$ in $100 \mathrm{ml}$ serum bottles) were conducted simultaneously, with periodic removal of pore water aliquots to monitor rates of anoxic $\mathrm{NO}_{3}{ }^{-}$consumption. (3) Sediment anammox rates were calculated based on ${ }^{29} \mathrm{~N}_{2}$ production in anaerobic incubations with the addition of ${ }^{15} \mathrm{NO}_{3}{ }^{-}$and ${ }^{14} \mathrm{NH}_{4}{ }^{+}(100 \mu \mathrm{M}$ each), while a parallel set of incubations with the addition of ${ }^{15} \mathrm{NH}_{4}{ }^{+}(100 \mu \mathrm{M})$ was conducted to evaluate air contamination or the presence of residual $\mathrm{NO}_{3}{ }^{-}$or $\mathrm{NO}_{2}{ }^{-}$during the incubation (Song \& Tobias, 2011). (4) Nitrification potential was measured in aerobic, sediment slurry incubations ( $60 \mathrm{~g}$ wet sediment $+60 \mathrm{ml}$ groundwater) in $100 \mathrm{ml}$ screw cap bottles with augmented background $\mathrm{NH}_{4}{ }^{+}$(as $\mathrm{NH}_{4} \mathrm{Cl}$ ) concentrations. Pore water was removed periodically, filtered, and assayed for $\mathrm{NO}_{3}{ }^{-}, \mathrm{NO}_{2}{ }^{-}$, and $\mathrm{NH}_{4}{ }^{+}$concentrations. Nitrification rates were calculated from net $\mathrm{NO}_{3}{ }^{-}+\mathrm{NO}_{2}{ }^{-}$accumulation with time. Rate measurements for all processes being assessed were determined using multiple, regressed time points; results are presented as the mean and standard deviation from individual incubations.

\subsection{In Situ Tracer Tests}

Two natural-gradient tracer tests were conducted in the lakebed sediments to measure the rates of net $\mathrm{NO}_{2}{ }^{-}$ consumption relative to the rates of transport through the sediments and subsequent delivery to the overlying surface water. Bromide $\left(\mathrm{Br}^{-}\right)$was the conservative tracer, while $\mathrm{NO}_{2}{ }^{-}$was chosen as the reactive tracer for both tests because of high background $\mathrm{NO}_{3}{ }^{-}$concentrations. Acetate tracer was used in the second test to examine the effect of degradable $\mathrm{C}$ (target concentrations for $\mathrm{NaBr}, \mathrm{NaNO}_{2}$, and $\mathrm{NaC}_{2} \mathrm{H}_{3} \mathrm{O}_{2}$ were $1,000,50$, and $100 \mu \mathrm{M}$, respectively, Table S8). A temporary grid of pushpoint samplers was installed in the lakebed sediments near the location of peak pore water $\mathrm{NO}_{3}{ }^{-}$concentration in October 2014 (Figure 2). The grid was approximately $60 \times 60 \mathrm{~cm}$ in map view with samplers set at multiple depths $(5$ to $75 \mathrm{~cm})$ at most locations (Figure S2). Also included in the grid were pore water surface samplers at two locations (Figure S1). The two tracer tests were conducted sequentially in the same grid and used the same injection port. The tracer solutions were prepared in a 113-L stainless steel barrel, which was first flushed for several hours with He and loaded with an anoxic, concentrated solution containing the tracer chemicals. In the field, $75 \mathrm{~L}$ of pore water was pumped into the barrel from two pushpoint samplers located near the sampling grid (approximately $5 \mathrm{~m}$ away) at a depth of $75 \mathrm{~cm}$. The contents of the barrel were mixed by agitation and then pumped into the center of the sampling grid at a depth of $75 \mathrm{~cm}$, producing a tracer cloud, which moved upward with natural groundwater flow (Figure S2). Samples of the injection solution were collected immediately prior to injection, from the injection port shortly after completing the injection process, and periodically from the pushpoint and pore water surface samplers by using a syringe attached to the sampler with tubing and a 
Table 1

Groundwater Seepage Rates Into Fishermans Cove and Lake Water Depth Near Location of Highest Pore Water Nitrate Concentration on Respective Sampling Excursions

\begin{tabular}{lcc}
\hline Date & Water depth $(\mathrm{cm})$ & Seepage rate $\left(\mathrm{L} \mathrm{m}^{-2} \mathrm{hr}^{-1}\right)$ \\
\hline June 2013 & nd & 3.6 \\
April 2014 & 57 & 4.2 \\
June 2014 & 38 & 7.3 \\
October 2014 & $13.5 / 15$ & $10.2 / 12.1$ \\
June 2015 & 40 & 5.4 \\
\hline
\end{tabular}

Note. nd $=$ not determined. plastic Luer valve. Samples were filtered and frozen for anion analysis (including $\mathrm{NO}_{3}{ }^{-}, \mathrm{NO}_{2}{ }^{-}$, and acetate) or injected into $30 \mathrm{ml} \mathrm{He}$-flushed serum bottles containing $\mathrm{KOH}$ for $\mathrm{N}_{2} \mathrm{O}$ analysis (Smith et al., 2004).

\subsection{Chemical Analyses}

Major cations, anions, and acetate were assayed using a Dionex ICS-5000 Ion Chromatograph with isocratic separation. Anions were separated with AG4A-SC and AS4A-SC guard and analytical columns and $1.8 \mathrm{mM}$ sodium carbonate/ $1.7 \mathrm{mM}$ sodium bicarbonate eluent. Cations were separated with CG12A and CS12A guard and analytical columns and $20 \mathrm{mM}$ methanesulfonic acid eluent. Acetate was separated with AG18-RFIC and AS18-RFIC guard and analytical columns and $28.5 \mathrm{mM} \mathrm{NaOH}$ eluent. DOC was determined using a platinum-catalyzed wet persulfate oxidation method (Aiken, 1992). Nitrous oxide was determined using a headspace equilibration method and an electron-capture-equipped gas chromatograph (Repert et al., 2014). Sediment C content, $\mathrm{KCl}$-extractable $\mathrm{NH}_{4}{ }^{+}$, and sediment-specific surface area were determined as previously described (Stoliker et al., 2016). Total Fe, magnesium (Mg), Mn, phosphorus $(\mathrm{P})$, sulfur $(\mathrm{S})$, and silica $(\mathrm{Si})$ were determined using inductively coupled plasma optical emission spectroscopy (Thermo Scientific, iCAP 6500). $\mathrm{N}$ and O stable isotope ratios in $\mathrm{NO}_{3}{ }^{-}+\mathrm{NO}_{2}{ }^{-}$were assayed and calibrated using the bacterial reduction method with Pseudomonas aureofaciens (Böhlke et al., 2003; Casciotti et al., 2002; Smith et al., 2017). Apparent values of $\delta^{18} \mathrm{O}$ determined by this method can be in error (lower than true values) because of an analytical artifact when $\mathrm{NO}_{2}{ }^{-}$is a significant fraction of total $\mathrm{NO}_{3}{ }^{-}+$ $\mathrm{NO}_{2}{ }^{-}$(Böhlke et al., 2007; Casciotti et al., 2007). Therefore, a subset of the samples was reanalyzed after treatment with sulfamic acid to remove $\mathrm{NO}_{2}^{-}$(Granger \& Sigman, 2009), including all samples with $\mathrm{NO}_{2}{ }^{-} / \mathrm{NO}_{3}{ }^{-}$ratios $>0.03$. To evaluate isotope fractionation effects, we selected data representing the isotopic composition of $\mathrm{NO}_{3}{ }^{-}$only, consisting of (1) all analyses of samples treated with sulfamic acid and (2) analyses of samples not treated with sulfamic acid, but with $\mathrm{NO}_{2}{ }^{-} / \mathrm{NO}_{3}{ }^{-}$ratios $<0.03$.

\subsection{Statistical Analysis}

Spearman's correlation analyses were conducted with the rate measurements, gene abundance, and environmental parameters monitored during the June samplings in 2014 and 2015 for 9 of 13 sediment samples (Tables S5 and S7). Excluded were APN-B, APN-Ox, APN-0, and APN1-3 because of missing data. Data were log-transformed to meet the assumptions of statistical inference for parametric tests and to reduce the range of data variation. The $\mathrm{R}$ program (The $\mathrm{R}$ Foundation for Statistical Computing) was used for the statistical analysis.

\section{Results}

\subsection{Hydrology, Geochemistry, and Stable Isotopes}

Groundwater, lake-sediment pore water, and lake sediments were collected on six dates, representing a range of lake stages over a 3-year period (Figure 1b). The difference in stage of $0.75 \mathrm{~m}$ between June 2013 and October 2014 caused the shoreline to retreat approximately $8 \mathrm{~m}$. The stage in October 2014 reached a 10-year low point. Natural-gradient tracer tests, involving reactive and nonreactive tracers, were conducted in the lake in October 2014.

The location of groundwater discharge into the lake was inferred by mapping pore water temperatures in the lake-bed sediments in June 2014, when groundwater temperatures were lower than lake-water temperatures (Figure 2). Lower temperatures along the shoreline indicated that focused groundwater discharge was occurring near the shoreline throughout the area surveyed. Lower temperatures offshore in the northwestern portion of the map extent indicated that groundwater was discharging in much of the northwestern portion of Fishermans Cove. The general trend of increasing temperatures with distance offshore in the northwestern area of Fishermans Cove indicated a general decrease in discharge rates with distance offshore. However, patches of colder water surrounded by warmer water several meters offshore from well site F744 indicated locations of locally greater discharge (Table 1). 
Table 2

Selected Sediment Characteristics and Potential Rates of Denitrification and Nitrification for Sediment Cores Collected From the Location of Nitrate-Contaminated Groundwater Discharge in Fishermans Cove in October 2014

\begin{tabular}{|c|c|c|}
\hline \multirow[b]{2}{*}{ Sediment parameter } & \multicolumn{2}{|c|}{ Depth interval } \\
\hline & $0-5 \mathrm{~cm}$ & $5-30 \mathrm{~cm}$ \\
\hline Specific surface area $\left(\mathrm{m}^{2} \mathrm{~g}^{-1}\right)$ & 0.68 & 0.24 \\
\hline Total carbon content $\left(\mu \mathrm{mol} \mathrm{C} \mathrm{gdw}^{-1}\right)$ & $221(17)$ & $131(5)$ \\
\hline Total nitrogen content $\left(\mu \mathrm{mol} \mathrm{N} \mathrm{gdw}{ }^{-1}\right)$ & $13.0(0.5)$ & $3.9(1.0)$ \\
\hline Extractable $\mathrm{NH}_{4}{ }^{+}\left(\mathrm{nmol} \mathrm{N} \mathrm{gdw}^{-1}\right)$ & $15.6(0.8)$ & $4.9(0.8)$ \\
\hline \multicolumn{3}{|l|}{ Denitrification rate $\left(\mathrm{nmol} \mathrm{N} \mathrm{gdw}{ }^{-1} \mathrm{hr}^{-1}\right)^{\mathrm{a}}$} \\
\hline$+\mathrm{NO}_{3}^{-}$ & $3.28(0.33)$ & $0.007(0.0003)$ \\
\hline$+\mathrm{NO}_{3}{ }^{-}+$acetate & $3.22(0.25)$ & $0.009(0.0004)$ \\
\hline \multicolumn{3}{|l|}{ Nitrification rate $\left(\mathrm{nmol} \mathrm{N} \mathrm{gdw}^{-1} \mathrm{hr}^{-1}\right)^{\mathrm{b}}$} \\
\hline ambient & $0.076(0.009)$ & nd \\
\hline$+\mathrm{NH}_{4}{ }^{+}$ & $0.113(0.006)$ & nd \\
\hline
\end{tabular}

${ }^{\mathrm{a}}$ Rates determined from linear regression of $\mathrm{N}_{2} \mathrm{O}$ production (5-6 time points) in the presence of $\mathrm{C}_{2} \mathrm{H}_{2}$ during triplicate, $0-20 \mathrm{hr}$, anoxic incubations at $15^{\circ} \mathrm{C}$. Initial added concentrations of $\mathrm{NO}_{3}{ }^{-}$and acetate were each $100 \mu \mathrm{M}$. ${ }^{\mathrm{b}}$ Rates determined from linear regression (7-8 time points) of $\mathrm{NO}_{3}{ }^{-}$production during triplicate, $0-6$ day, oxic incubations at $15{ }^{\circ} \mathrm{C}$. Initial dissolved $\mathrm{NH}_{4}{ }^{+}$concentrations were 3 and $54 \mu \mathrm{M}$ for the ambient and added $\mathrm{NH}_{4}{ }^{+}$, respectively. Parentheses enclose standard error; $\mathrm{gdw}=$ gr dry weight; $\mathrm{nd}=$ not determined; $n=3$ for total $\mathrm{C}$ and $\mathrm{N}$ analyses.

Total sediment $\mathrm{C}$ content at the study location was relatively low within the 5-30 $\mathrm{cm}$ depth interval but slightly higher in the near-surface $(0-5 \mathrm{~cm})$ sediments $\left(131\right.$ and $221 \mu \mathrm{mol} \mathrm{C}$ (g dry sediment) ${ }^{-1}$, respectively; Table 2). Extractable $\mathrm{NH}_{4}{ }^{+}$was very low for both depth intervals (Table 2).

Vertical profiles of groundwater chemistry show concentration gradients related to the wastewater contaminant plume at two upgradient locations (F424 and F744) within $20 \mathrm{~m}$ of the shoreline of Ashumet Pond (Figures 3a and 3b). The F424 groundwater profile shows shallow, uncontaminated, oxic groundwater (with the exception of a thin, $\mathrm{O}_{2}$-deficient zone in the shallowest part of the profiles related to the presence of parking lot pavement in the immediate area) underlain by suboxic (less than atmospheric equilibrium) and anoxic contaminated plume water with elevated concentrations of $\mathrm{NO}_{3}{ }^{-}, \mathrm{NH}_{4}{ }^{+}$, and DOC. The peak $\mathrm{NO}_{3}{ }^{-}$concentration of $132 \mu \mathrm{M}$ was located at $\sim 10 \mathrm{~m}$ elevation, and low-level concentrations of $\mathrm{NO}_{2}{ }^{-}$and $\mathrm{N}_{2} \mathrm{O}$, up to about $3 \mu \mathrm{M}$, were located below the $\mathrm{NO}_{3}{ }^{-}$peak. DOC concentrations within the contaminant plume were 65-95 $\mu \mathrm{M}$. Similar vertical patterns were evident at F744, which is near the lakeshore and
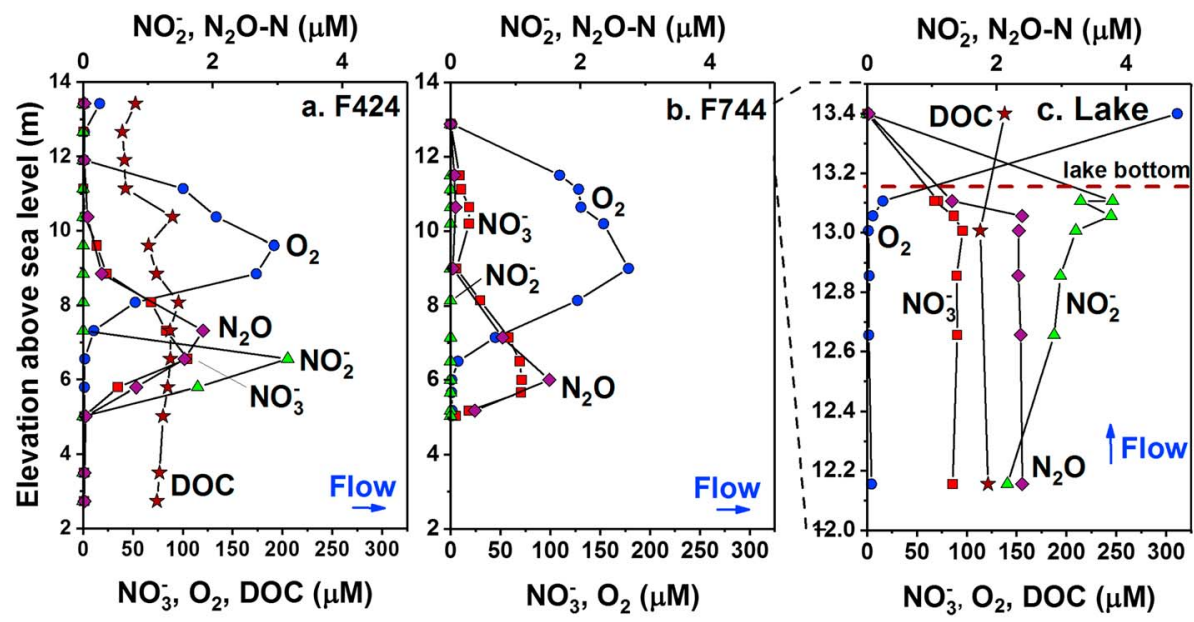

Figure 3. Depth profiles of dissolved oxygen, nitrate, nitrite, and nitrous oxide concentrations at (a) well F424, (b) well F744, and (c) a groundwater discharge location in Ashumet Pond in October 2014 (see Figure 2 for locations). F424 dissolved organic carbon (DOC) concentrations are from June 2014. Lake water values in Figure 3c are arbitrarily plotted at $25 \mathrm{~cm}$ above the sediment surface. Arrows indicate that groundwater flows laterally from F424 to F744 and then upward at the lake. (Note that the contaminant plume at F424 extends down to an elevation of about -15 m, below the nitrate zone shown here; see Repert et al., 2006.). Data in Table S2. 

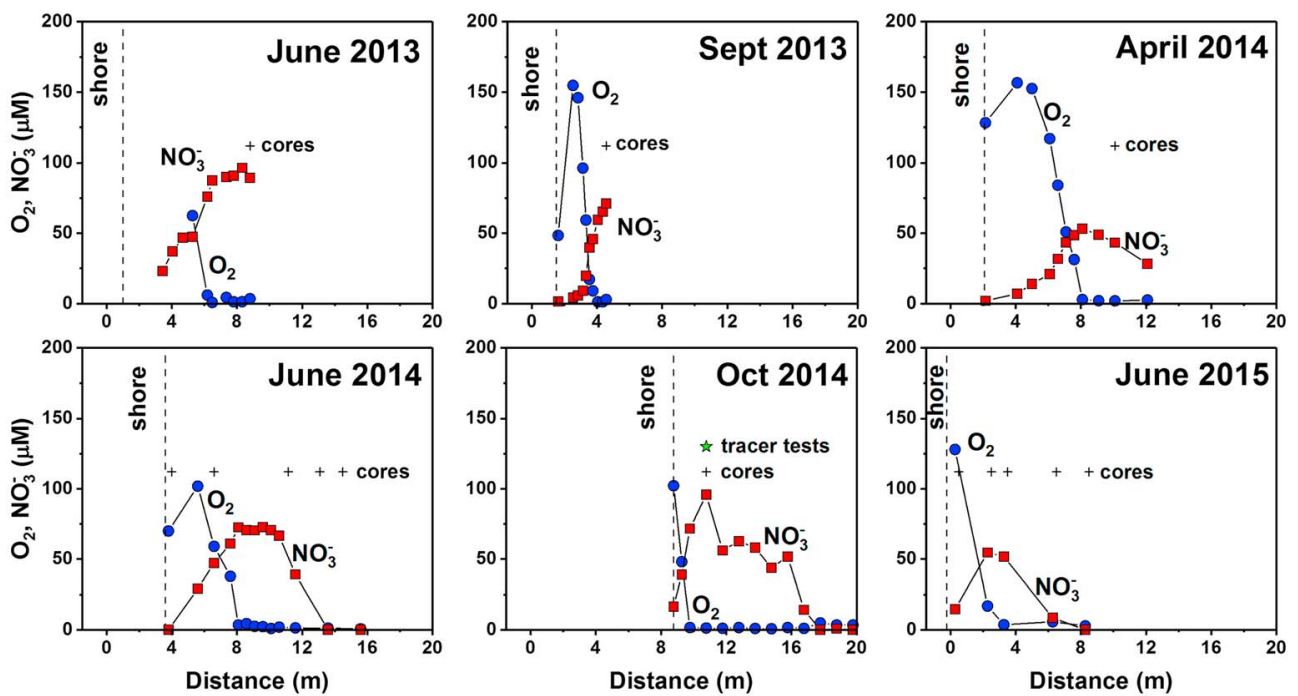

Figure 4. Seasonal shift in shore position and horizontal gradients of dissolved oxygen and nitrate concentrations in lakebed pore water along transects A-F perpendicular to shore, as indicated in Figure 2, at a depth of $15 \mathrm{~cm}$ below the sediment-water interface. Location of sediment core collection sites for each sampling excursion and the tracer test location in October 2014 are indicated. Distance is relative to June 2013 shoreline, which was arbitrarily set as $1 \mathrm{~m}$. Groundwater flow at these transects is generally upward from beneath the transect. Data in Table S3.

approximately downgradient from F424 (Figures 1 and 2). Groundwater flow upgradient of the lake is largely horizontal, such that peak concentrations of $\mathrm{O}_{2}, \mathrm{NO}_{3}{ }^{-}$, and $\mathrm{N}_{2} \mathrm{O}$ occurred at nearly identical elevations at F744 and F424.

Pore water profiles in the upper $1 \mathrm{~m}$ of lakebed sediments, at locations where high $\mathrm{NO}_{3}{ }^{-}$groundwater was discharging, were relatively uniform with depth (Figure 3c). The largest chemical gradients were near the sediment-water interface $(0-10 \mathrm{~cm})$, where $\mathrm{O}_{2}$ increased abruptly from near zero in the pore water to near saturation relative to the atmosphere in the lake, and $\mathrm{NO}_{3}{ }^{-}, \mathrm{NO}_{2}{ }^{-}$, and $\mathrm{N}_{2} \mathrm{O}$ concentrations decreased upward toward lake water values. DOC concentrations were relatively similar in the pore water and overlying lake water.

The pattern of horizontal concentration gradients of dissolved $\mathrm{O}_{2}$ and $\mathrm{NO}_{3}{ }^{-}$in pore water samples collected at a depth of $15 \mathrm{~cm}$ below the sediment-water interface along transects perpendicular to shore (Figure 4) was similar to the pattern of vertical concentration gradients in groundwater at the upgradient well sites (Figure 3). Dissolved $\mathrm{O}_{2}$ concentrations decreased and $\mathrm{NO}_{3}{ }^{-}$concentrations increased with distance along each transect out into the lake. The location of the transition between oxic groundwater with low $\mathrm{NO}_{3}{ }^{-}$concentrations and anoxic groundwater with $50-100 \mu \mathrm{M} \mathrm{NO}_{3}{ }^{-}$changed with time. For example, results from October 2014 and September 2015 illustrate that lakebed sediments located at 4-5 $\mathrm{m}$ along the horizontal distance scale from the arbitrary reference point $(0 \mathrm{~m})$ on shore were exposed to anoxic, $\mathrm{NO}_{3}{ }^{-}$-contaminated groundwater at high lake stages and to oxic groundwater or air at lower lake stages (Figure 4).

The isotopic composition of $\mathrm{NO}_{3}{ }^{-}\left(\delta^{18} \mathrm{O}\right.$ and $\left.\delta^{15} \mathrm{~N}\right)$ was highly variable in the $\mathrm{F} 744$ groundwater profile upgradient of the lake (Figure 5). The slope of the groundwater data $\left(\Delta \delta^{18} \mathrm{O} / \Delta \delta^{15} \mathrm{~N}\right)$ in the part of the profile where $\left[\mathrm{NO}_{3}{ }^{-}\right]>20 \mu \mathrm{M}$ was approximately $0.75\left(R^{2}=0.98\right)$, which is similar to the slope of 0.73 previously attributed to $\mathrm{NO}_{3}{ }^{-}$reduction within other portions of the treated-wastewater groundwater plume at the Cape Cod site (Böhlke et al., 2006) and within the range of values (0.5-1) attributed to $\mathrm{NO}_{3}{ }^{-}$reduction elsewhere (Böttcher et al., 1990; Granger et al., 2008; Granger \& Wankel, 2016). Variation of $\mathrm{NO}_{3}{ }^{-} \Delta \delta^{18} \mathrm{O} / \Delta \delta^{15} \mathrm{~N}$ slopes in such environments may indicate transient reoxidation \pm isotopic exchange during net $\mathrm{NO}_{3}{ }^{-}$reduction involving denitrification or anammox (Brunner et al., 2014; Granger \& Wankel, 2016), both of which have been documented in the groundwater plume at the Cape Cod site (Smith et al., 2015). The isotope data indicate that substantial and variable $\mathrm{NO}_{3}{ }^{-}$reduction had occurred in the contaminated groundwater approaching the lake from the northwest, as demonstrated previously (Smith et al., 2004; Smith, Howes, et al. 1991). 


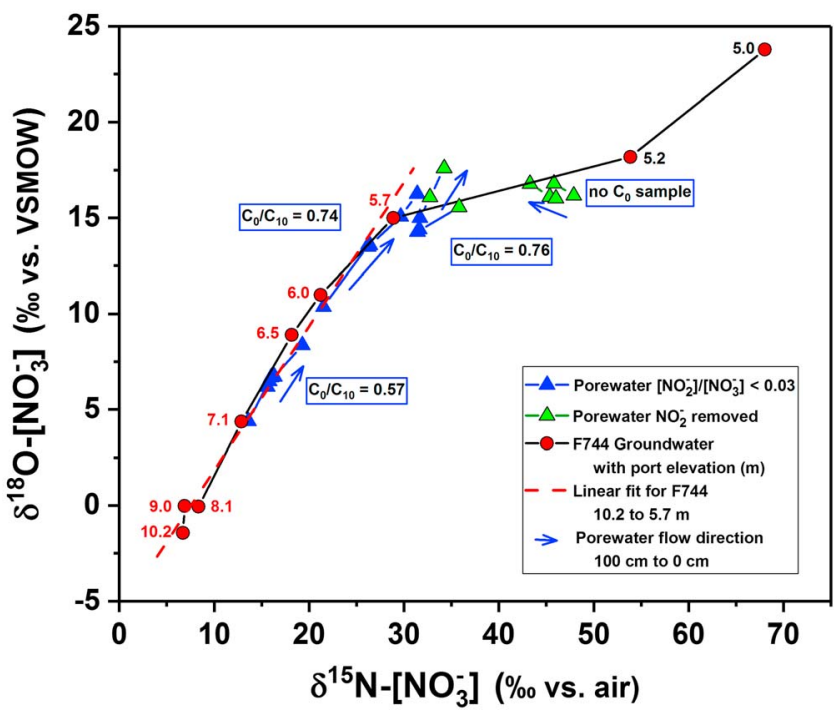

Figure 5. $\delta^{15} \mathrm{~N}$ and $\delta^{18} \mathrm{O}$ values of nitrate in upgradient groundwater (well F744, October 2014) and lakebed pore water (four depth profiles, June 2015). Numbers next to well data points indicate sample port elevation (m); red line is linear regression of data from groundwater ports where $\left[\mathrm{NO}_{3}{ }^{-}\right]>20 \mu \mathrm{M}$ $\left(R^{2}=0.98,\left[\Delta \delta^{18} \mathrm{O} / \Delta \delta^{15} \mathrm{~N}\right]=0.75\right)$. Arrows indicate direction of pore water flow (upward from $100 \mathrm{~cm}$ depth to 10 or $0-5 \mathrm{~cm}$ ). Boxes indicate nitrate concentration changes for sample pairs between 10 and $0-5 \mathrm{~cm}$ depth intervals $\left(\left[\mathrm{C}_{0 \mathrm{~cm}} / \mathrm{C}_{10 \mathrm{~cm}}\right]_{\mathrm{NO} 3}=0.57\right.$ to 0.76$)$, after adjustment for lake water dilution by using dissolved $\mathrm{Si}$ concentrations $\left(\left[\mathrm{C}_{0 \mathrm{~cm}} / \mathrm{C}_{10 \mathrm{~cm}}\right]_{\mathrm{Si}}=0.42\right.$ to $0.64)$ for each pore water profile location. Data in Table S2.
Lateral variations in $\delta^{18} \mathrm{O}$ and $\delta^{15} \mathrm{~N}$ of pore water $\mathrm{NO}_{3}{ }^{-}$beneath the lakebed on scales of meters were similar to vertical variations in upgradient groundwater on similar scales (Figure 5) and support the hypothesis that much of the $\mathrm{NO}_{3}{ }^{-}$reduction experienced by the discharging groundwater occurred in upgradient areas of the aquifer and was not related to the lake. The isotope results support the hypothesis that the horizontal distribution of plume geochemistry beneath the lakebed was largely inherited from the vertical distributions of plume constituents in the upgradient groundwater. In effect, the vertical distributions rotated about $90^{\circ}$ and were mapped on the lake bottom as the groundwater flow direction curved upward from nearly horizontal flow in the aquifer to nearly vertical flow in the discharge area at the lake.

Vertical profiles of $\mathrm{NO}_{3}{ }^{-}$isotopic composition and concentration in pore water between the 10 and $100 \mathrm{~cm}$ depths exhibited minor variations but generally were not consistent with progressive $\mathrm{NO}_{3}{ }^{-}$reduction during upward flow beneath the lakebed. However, in the top $10 \mathrm{~cm}$, at least three out of four pore water profiles exhibited upward increases in $\delta^{18} \mathrm{O}$ and $\delta^{15} \mathrm{~N}$ associated with upward decreases in $\mathrm{NO}_{3}{ }^{-}$concentration, which is consistent with local $\mathrm{NO}_{3}{ }^{-}$reduction just below the lake-bottom surface (Table S2). These shallow isotopic differences were small, and apparent $\mathrm{NO}_{3}{ }^{-}$losses had large uncertainties because of mixing (dilution) with surface water near the sediment surface during sampling, so estimated isotope fractionation factors were not well defined. In the uppermost $10 \mathrm{~cm}$ in three profiles, $\delta^{15} \mathrm{~N}\left[\mathrm{NO}_{3}{ }^{-}\right]$values increased upward by 1.5 to $3.0 \%$ $\left(\Delta \delta^{15} \mathrm{~N}\left[\mathrm{NO}_{3}{ }^{-}\right]\right.$), while estimated fractional losses ranged from 24 to $43 \%$ (1-C/ $\left.\mathrm{C}_{0}\left[\mathrm{NO}_{3}{ }^{-}\right]\right)$, after adjustment for dissolved Si dilution by surface water mixing (Figure 5). These gradients yielded apparent isotope fractionation factors $\left(\varepsilon^{15} \mathrm{~N}\right)$ of $-5.5 \pm$ $0.3 \%$, which could be qualitatively consistent with net $\mathrm{NO}_{3}{ }^{-}$reduction in a heterogeneous environment subjected to local dispersion and diffusion in the groundwater discharge area near the sediment-water interface. Comparable data are not available for the fourth profile, where the shallowest sample was more diluted with surface water, had higher $\mathrm{NO}_{2}{ }^{-} / \mathrm{NO}_{3}{ }^{-}$ratios $(0.04$ to 0.1$)$, and yielded discordant $\delta^{18} \mathrm{O}, \delta^{15} \mathrm{~N}$, and $\varepsilon^{15} \mathrm{~N}$ results from analyses of $\left[\mathrm{NO}_{3}^{-}+\mathrm{NO}_{2}^{-}\right]$versus $\left[\mathrm{NO}_{3}^{-}\right]$.

\subsection{Sediment Incubations and N Cycle Gene Abundance}

Activity assays for denitrification, anammox, and $\mathrm{NO}_{3}{ }^{-}$consumption were conducted using short-term anoxic sediment microcosm experiments. Potential rates of denitrification were 10 to 470 times higher in near-surface sediments $(0-5 \mathrm{~cm})$ than in pooled deeper sediments $(5-30 \mathrm{~cm})$ at the $\mathrm{NO}_{3}{ }^{-}$discharge zone (Table 2, Figure 6a), with no clear correlation with sediment pore water $\mathrm{NO}_{3}{ }^{-}$concentrations along the horizontal transect perpendicular to shore (compare Figures 4 and 6a). The ranges of abundance of nosZI, nosZII, and nirS genes from all samples were $1.8 \times 10^{7}$ to $1.6 \times 10^{8}, 1.4 \times 10^{7}$ to $1.9 \times 10^{8}$, and $4.3 \times 10^{6}$ to $3.86 \times 10^{7}$ copies (g dry sediment) ${ }^{-1}$, respectively (Table S7). The nirS abundance was substantially higher in the near-surface sediments than in the pooled deeper sediments. The nosZI and nosZII gene abundances were also higher in the near-surface sediments, with the highest abundances measured in the near-surface sediments with highest pore water $\mathrm{NO}_{3}{ }^{-}$concentrations (Figure 6a, Table S7). Significant and positive correlations among nirS, nosZI, and nosZII were found by using Spearman's correlation analysis $(r=0.87$ and 0.86 , respectively, Table 3), indicating functional linkage of microbes reducing $\mathrm{NO}_{2}{ }^{-}$and $\mathrm{N}_{2} \mathrm{O}$ in the sediments, even though the abundance of total nosZ genes (combined nosZI and nosZII) was at least 1 order of magnitude higher than the nirS gene abundance. Denitrification rates were also shown to have significant and positive correlation with all three genes. In addition, more detailed depth profiles in June 2015 indicated that a decrease in denitrification rates and gene abundance occurred with increasing depth primarily in the top $10 \mathrm{~cm}$ of the sediment profile (Figure 6a). Addition of acetate to the microcosm incubations had no measurable effect on potential rates of denitrification (Table 2), which agrees with no significant correlation between total sediment C (\% C) and denitrification rates or gene measurements (Table 3). 

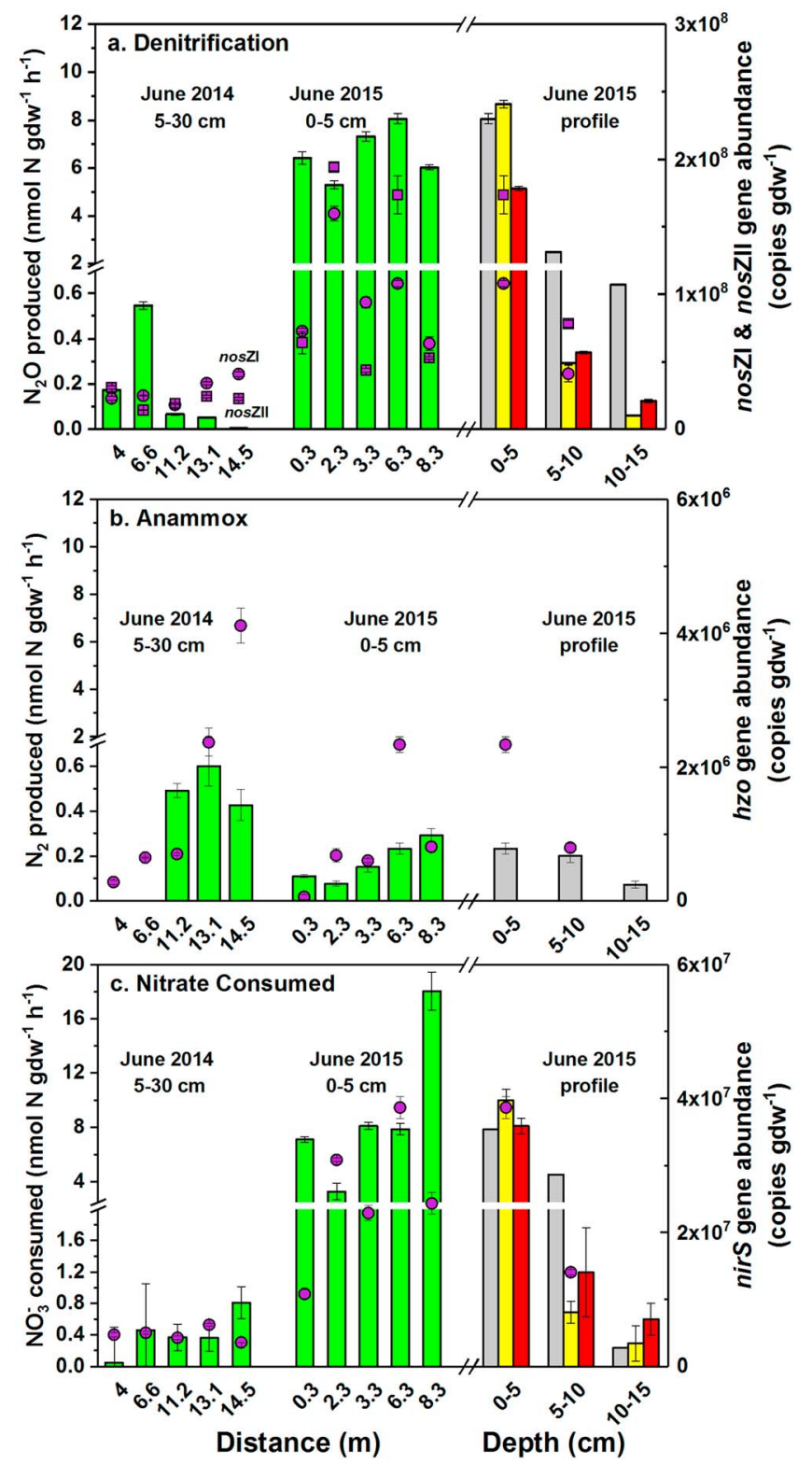

Figure 6. Genes (data points) regulating denitrification (nosZI, nosZII, and nirS) and anammox ( $h z o$ ) and potential rates of denitrification, anammox, and net anoxic nitrate consumption (bars) grouped by sampling transect and date (green bars) and depth interval (grey, yellow, and red bars represent replicates) within sediment cores. Distance is relative to a fixed location onshore (sediment was collected from transects C [June 2014] and F [June 2015] shown in Figure 2). Results from depth profiles of replicate cores collected at a distance of $6.3 \mathrm{~m}$ are shown for June 2015. See Table 3 for correlation between rates and gene abundances. Error bars are \pm 1 standard deviation. Data in Tables S6 and S7.
In contrast to denitrification, potential rates of anammox along the transects were higher in the pooled deeper sediments than in the near-surface sediments, although the difference between the depth intervals was not as great as the difference for potential rates of denitrification, and there was an apparent rate decrease with depth in the 0-15 cm interval in June 2015 (Figure 6b). Potential rates of anammox appeared to have a significant and positive correlation with the hzo gene abundance but are negatively correlated with the denitrification genes (Table 3). The hzo gene abundance ranged from $6.1 \times 10^{4}$ to $4.1 \times 10^{6}$ copies (g dry sediment) ${ }^{-1}$ and was lowest at and near the shore, increasing linearly with distance at the three locations farthest from shore (Figure 6b). However, the nearsurface sediments collected in June 2015 did not have the same trend as in the deeper sediments, as the highest abundance of hzo gene was measured in the near-surface sediment $6.3 \mathrm{~m}$ from shore.

Potential rates of net $\mathrm{NO}_{3}{ }^{-}$consumption were $0.05-18.1 \mathrm{nmol} \mathrm{N}$ loss (g dry sediment $)^{-1} \mathrm{hr}^{-1}$, with higher rates measured in the pooled sediment samples in June 2015 (Figure 6c). The near-surface sediments $(0-5 \mathrm{~cm})$ had higher rates than the pooled deeper sediments $(5-30 \mathrm{~cm})$, similar to the pattern for the denitrification rates. Interestingly, potential $\mathrm{NO}_{3}{ }^{-}$consumption rates for the two depth intervals along the transects did not differ as much as might be expected, given the $\mathrm{NO}_{3}{ }^{-}$and $\mathrm{O}_{2}$ concentration differences that were present along the transects. Abundances of nirS and nosZI genes were significantly positively correlated with the $\mathrm{NO}_{3}{ }^{-}$ consumption rates, as was total sediment $\mathrm{C}(\% \mathrm{C})$, the latter having the highest coefficient ( $r=0.865)$ among the geochemical parameters compared (Table 3).

Rates of nitrification in the sediments collected from $\mathrm{NO}_{3}{ }^{-}$discharge zones at ambient $\mathrm{NH}_{4}{ }^{+}$concentrations were very low $\left(0.076 \mathrm{nmol} \mathrm{N} \mathrm{g}{ }^{-1}\right.$ $\mathrm{hr}^{-1}$ ) in October 2014 (Table 2). The addition of $\mathrm{NH}_{4}{ }^{+}$increased the potential rate approximately $50 \%$, indicating that an active nitrifying community was present in the near-surface sediments, even though there was no detectable dissolved $\mathrm{NH}_{4}{ }^{+}$present in the sediment pore water at that location.

\subsection{In Situ Tracer Tests}

Two natural-gradient tracer tests designed to quantify rates of $\mathrm{NO}_{3}{ }^{-}$ reduction were conducted consecutively at the peak $\mathrm{NO}_{3}{ }^{-}$discharge location in October 2014. Observations in the array of samplers near the sediment-water interface (Figure S2) showed that $\mathrm{Br}^{-}$was detected only at samplers located directly above the initial location of the injected tracer cloud, confirming that flow was vertical or nearly vertical within $75 \mathrm{~cm}$ of the sediment-water interface at the tracer test location. Breakthrough curves of normalized concentrations of $\mathrm{NO}_{2}{ }^{-}$and $\mathrm{Br}^{-}$from the first test indicate net $\mathrm{NO}_{2}{ }^{-}$loss with upward distance traveled as the tracer cloud discharged into the surface water of the lake (Figures 7a and 7b). An increase in $\mathrm{N}_{2} \mathrm{O}$ concentrations at peak breakthrough in the top two samplers (5 $\mathrm{cm}$ pushpoint sampler and the pore water surface sampler) accompanied the $\mathrm{NO}_{2}{ }^{-}$loss; at peak breakthrough, the $\mathrm{Br}^{-}$-normalized net loss of $\mathrm{NO}_{2}{ }^{-}$was up to $20 \%$ of the injected tracer concentration (Figures $7 \mathrm{c}$ and $7 \mathrm{~d}$ ). The rate of $\mathrm{NO}_{2}{ }^{-}$loss was relatively low during transit through the 75 to $12 \mathrm{~cm}$ interval then increased substantially during transit through the 12 to $2.5 \mathrm{~cm}$ interval (Table 4; see Table 4 footnote for definition of depth intervals used in rate calculations; also note that sediment depth intervals are given as deepest to shallowest, that is, in direction of pore water flow). $\mathrm{Net}_{2} \mathrm{O}$ 
Table 3

Spearman's Correlation Analysis of Sedimentary N Cycling Activities With Gene Abundance and Environmental Parameters Measured in Fishermans Cove ${ }^{a}$

\begin{tabular}{|c|c|c|c|c|c|c|c|c|c|c|}
\hline \multirow[b]{2}{*}{$\mathrm{N}$ cycle process } & \multicolumn{2}{|c|}{ hzo gene } & \multicolumn{2}{|c|}{ nirS gene } & \multicolumn{2}{|c|}{ nosZI gene } & \multicolumn{2}{|c|}{ nosZII gene } & \multicolumn{2}{|c|}{ Nitrate } \\
\hline & $\mathrm{r}$ & $p$ value & $\mathrm{r}$ & $p$ value & $\mathrm{r}$ & $p$ value & $\mathrm{r}$ & $p$ value & $\mathrm{r}$ & $p$ value \\
\hline Anammox & 0.720 & $<0.05$ & -0.476 & $>0.05$ & -0.756 & $<0.05$ & -0.695 & $<0.05$ & 0.229 & $>0.05$ \\
\hline Denitrification & -0.200 & $>0.05$ & 0.874 & $<0.05$ & 0.782 & $<0.05$ & 0.719 & $<0.05$ & -0.598 & $>0.05$ \\
\hline \multirow[t]{2}{*}{ Nitrate consumption } & 0.053 & $>0.05$ & 0.733 & $<0.05$ & 0.726 & $<0.05$ & 0.558 & $>0.05$ & -0.293 & $>0.05$ \\
\hline & \multicolumn{2}{|c|}{ Ammonium } & \multicolumn{2}{|c|}{ Iron } & \multicolumn{2}{|c|}{ Manganese } & \multicolumn{2}{|c|}{ Sulfur } & \multicolumn{2}{|c|}{ Sediment C } \\
\hline $\mathrm{N}$ cycle process & $r$ & $p$ value & $r$ & $p$ value & $r$ & $p$ value & $r$ & $p$ value & $r$ & $p$ value \\
\hline Anammox & 0.415 & $>0.05$ & -0.418 & $>0.05$ & -0.330 & $>0.05$ & -0.418 & $>0.05$ & -0.287 & $>0.05$ \\
\hline Denitrification & -0.547 & $>0.05$ & 0.979 & $<0.05$ & 0.911 & $<0.05$ & 0.664 & $>0.05$ & 0.600 & $>0.05$ \\
\hline Nitrate consumption & -0.338 & $>0.05$ & 0.760 & $<0.05$ & 0.700 & $<0.05$ & 0.798 & $<0.05$ & 0.865 & $<0.05$ \\
\hline
\end{tabular}

${ }^{\mathrm{a}}$ Activities measured as potential rates in microcosm incubations in nmol N (g dry weight) ${ }^{-1} \mathrm{hr}^{-1}$; gene abundances as number of copies (g dry weight) ${ }^{-1}$; $\mathrm{NO}_{3}{ }^{-}, \mathrm{NH}_{4}{ }^{+}, \mathrm{Fe}^{+2}, \mathrm{Mn}^{+2}$, and sulfur as $\mu$ Molar pore water concentrations on the date of sampling; and sediment $\mathrm{C}$ as percent of total $\mathrm{C}$ content. Analyses included nine sediment samples collected in June 2014 and 2015 (see Tables S5 and S7, excluding four samples with incomplete data).

production near the surface accounted for $47 \%$ of the $\mathrm{NO}_{2}{ }^{-}$consumed in the center of the tracer cloud. The average vertical velocity of the tracer cloud, as measured between the breakthrough curve peaks, was $4.3 \mathrm{~cm}$ $\mathrm{hr}^{-1}$ (Table 4). Assuming an effective porosity of 0.3 for sandy sediments (LeBlanc, 1984), a pore velocity of $4.3 \mathrm{~cm} \mathrm{hr}^{-1}$ corresponds to a seepage rate of $12.9 \mathrm{~L} \mathrm{~m}^{-2} \mathrm{hr}^{-1}$. This compares favorably with the seepage rate measured adjacent to the tracer test site (Table 1) considering local-scale variations in seepage rate up to a factor of 2 owing to subtle small-scale spatial heterogeneities in permeability (Rosenberry \& Menheer, 2006) and up to a factor of 1.8 owing to potential artifacts related to seepage meter design (Rosenberry \& LaBaugh, 2008). Nitrate concentrations during breakthrough varied between ambient groundwater values
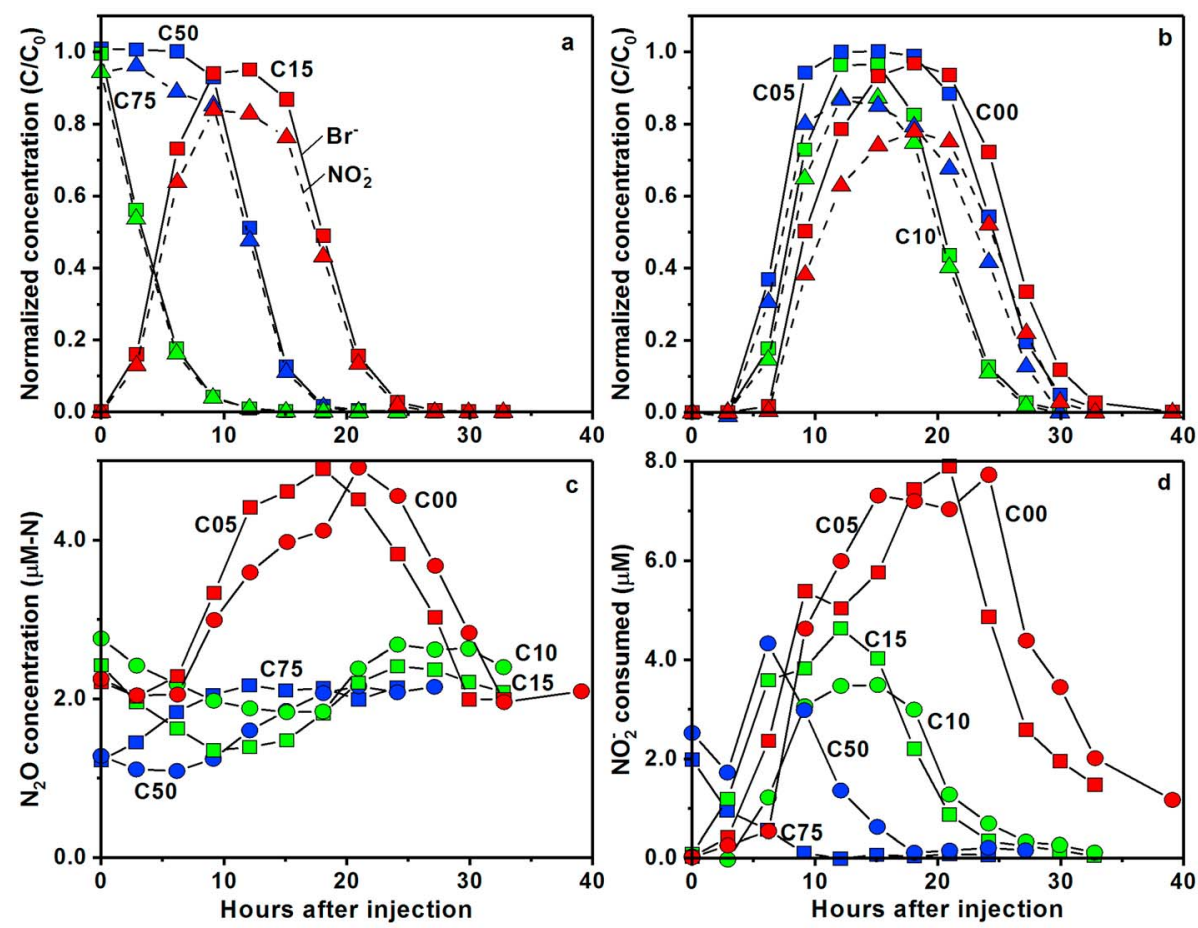

Figure 7. Breakthrough curves for a natural-gradient tracer test with nitrite (triangles) and bromide (squares) conducted in Ashumet Pond in October 2014 at location C (see Figures 2 and S2) at indicated depths (cm). (a, b) Normalized concentrations of nitrite and bromide at six sampling depths, (c) nitrous oxide concentrations, and (d) calculated amount of nitrite tracer consumed (relative to bromide). Data in Tables S8 and S9. 
Table 4

Net Rates of Nitrite, Nitrate, and Acetate Consumption and Nitrous Oxide Production During the October 2014 Natural-Gradient Tracer Tests in Fishermans Cove Sediments at the Location of Nitrate-Contaminated Groundwater Discharge ${ }^{a}$

\begin{tabular}{|c|c|c|c|c|c|}
\hline \multirow[b]{2}{*}{ Travel interval } & \multicolumn{2}{|c|}{ Tracer test $1^{b}$} & \multicolumn{3}{|c|}{ Tracer test $2^{c}$} \\
\hline & $\mathrm{NO}_{2}{ }^{-}$consumption rate & $\mathrm{N}_{2} \mathrm{O}$ production rate & $\mathrm{NO}_{3}{ }^{-}$consumption rate & $\mathrm{N}_{2} \mathrm{O}$ production rate & Acetate consumption rate \\
\hline 75 to $12 \mathrm{~cm}$ & 0.15 & 0.03 & 0.05 & 0.13 & 1.17 \\
\hline 12 to $2.5 \mathrm{~cm}$ & 0.54 & 0.56 & 3.26 & 0.98 & 3.08 \\
\hline Vertical velocity $^{\mathrm{d}}$ & $4.3 \mathrm{~cm} \mathrm{hr}^{-1}$ & $4.8 \mathrm{~cm} \mathrm{hr}^{-1}$ & & & \\
\hline
\end{tabular}

${ }^{\mathrm{a}}$ Rates $\left(\mu \mathrm{mol} \mathrm{N} \mathrm{L}{ }^{-1} \mathrm{hr}^{-1}\right.$ or $\mu \mathrm{mol}$ acetate $\mathrm{L}^{-1} \mathrm{hr}^{-1}$ ) calculated from differences in normalized tracer concentrations at breakthrough curve peaks, $12 \mathrm{~cm}$ calculated as average of $\mathrm{C} 10$ and $\mathrm{C} 15$ samplers, and $2.5 \mathrm{~cm}$ calculated as average of C00 and C05 samplers. Sampler designations are site C (location shown in Figure S2) and depth in centimeter below the lakebed. ${ }^{b}$ Tracer constituents were $\mathrm{NaBr}$ and $\mathrm{NaNO}_{2}$ at 1,000 and $25 \mu \mathrm{M}$, respectively. ${ }^{c}$ Tracer constituents

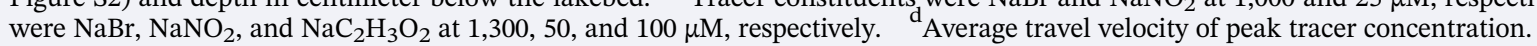

(prior to and after the arrival of the tracer cloud) and the injectate value (the $\mathrm{NO}_{3}{ }^{-}$concentration in the tracer solution source water and the injection port differed slightly), indicating no significant loss of $\mathrm{NO}_{3}{ }^{-}$ during transport (Table S9).

The second tracer test was a repeat of the first test with $\mathrm{NO}_{2}{ }^{-}$, but with the addition of $\mathrm{NaC}_{2} \mathrm{H}_{3} \mathrm{O}_{2}$ as a second reactive tracer to determine whether the addition of a labile organic- $\mathrm{C}$ source would increase reduction of tracer $\mathrm{NO}_{2}{ }^{-}$and (or) ambient $\mathrm{NO}_{3}{ }^{-}$in the injectate source water. During this test, $\mathrm{NO}_{3}{ }^{-}$concentrations during breakthrough at depths from 75 to $15 \mathrm{~cm}$ varied between the ambient groundwater and injectate values, indicating no reactive loss of $\mathrm{NO}_{3}{ }^{-}$. In contrast, significant losses of $\mathrm{NO}_{3}{ }^{-}$were observed near the sediment surface (Figure 8a). Nitrous oxide concentrations were also relatively constant below $10 \mathrm{~cm}$ but increased within the tracer cloud near the sediment surface (Figure 8c) and to a greater extent than during the first tracer test. Tracer $\mathrm{NO}_{2}{ }^{-}$concentrations were relatively constant at most depths (Table S9) but had a transient increase when the tracer cloud passed through the uppermost $5 \mathrm{~cm}$ depth interval (Figure 8d, negative consumption values). Acetate consumption was evident from $15 \mathrm{~cm}$ upward, though the amount of acetate consumed was greatest in the top $5 \mathrm{~cm}$ (Figure 8b). The rate of $\mathrm{NO}_{3}{ }^{-}$consumption in the top $12 \mathrm{~cm}$ in the presence of acetate was 6 times the $\mathrm{Br}^{-}$-normalized net $\mathrm{NO}_{2}{ }^{-}$consumption rate in tracer test 1 , and $\sim 19 \%$ of the acetate-amended denitrification rates that were measured in the well-mixed, laboratory microcosms ( 0.61 versus $3.22 \mathrm{nmol} \mathrm{N}$ (g dry sediment $)^{-1} \mathrm{hr}^{-1}$, Tables 2 and 4; conversion using a porosity of 0.3 and sand bulk density of $1.6 \mathrm{~g} \mathrm{~cm}^{-3}$ ). In tracer test 2 , the rate of $\mathrm{Br}^{-}$-normalized acetate consumption in the top $12 \mathrm{~cm}$ was 2 to 3 times the rate in the deeper sediments. The net $\mathrm{N}_{2} \mathrm{O}$ production rate in the top $12 \mathrm{~cm}$ in tracer test 2 (with acetate present) was approximately 2 times the rate measured in tracer test 1 (no acetate) in the same interval (Table 4).

\section{Discussion}

\subsection{Hydrologic Controls on Groundwater Nitrogen Discharge Patterns}

The groundwater chemistry of the wastewater contaminant plume discharging into Ashumet Pond has distinct vertical gradients that have been previously documented and were reaffirmed in this study (McCobb et al., 2003; Repert et al., 2006; Smith, Harvey, et al., 1991; Stoliker et al., 2016). The gradients divide the aquifer vertically into three zones relative to $\mathrm{N}$ concentrations and speciation. There is a shallow, generally oxic, uncontaminated zone near the water table in which the inorganic $\mathrm{N}$ occurs as $\mathrm{NO}_{3}{ }^{-}$at concentrations typical of uncontaminated groundwater in the area. Below the uncontaminated zone is an oxic to anoxic $\mathrm{NO}_{3}{ }^{-}-$ containing zone that is about 5-6 m thick and often contains subzones of $\mathrm{NO}_{2}{ }^{-}$and $\mathrm{N}_{2} \mathrm{O}$, and a deeper anoxic zone in which inorganic $\mathrm{N}$ exists as $\mathrm{NH}_{4}{ }^{+}$with no $\mathrm{NO}_{3}{ }^{-}$. The vertical locations of boundaries between these zones vary somewhat with time (e.g., Repert et al., 2006), but the general separation of the $\mathrm{NO}_{3}{ }^{-}$and $\mathrm{NH}_{4}{ }^{+}$zones is persistent, which is consistent with minimal vertical dispersion affecting contaminant transport within the aquifer (Garabedian et al., 1991; Repert et al., 2006). At any fixed location, the vertical pattern of the gradients generally remains constant with time, and there is little change as the water table elevation changes in response to seasonal variations in aquifer recharge. Only the thickness of the uncontaminated zone immediately below the water table changes (see Repert et al., 2006). Upgradient of the lake, groundwater flows primarily in a horizontal direction. Even within a few meters of the 

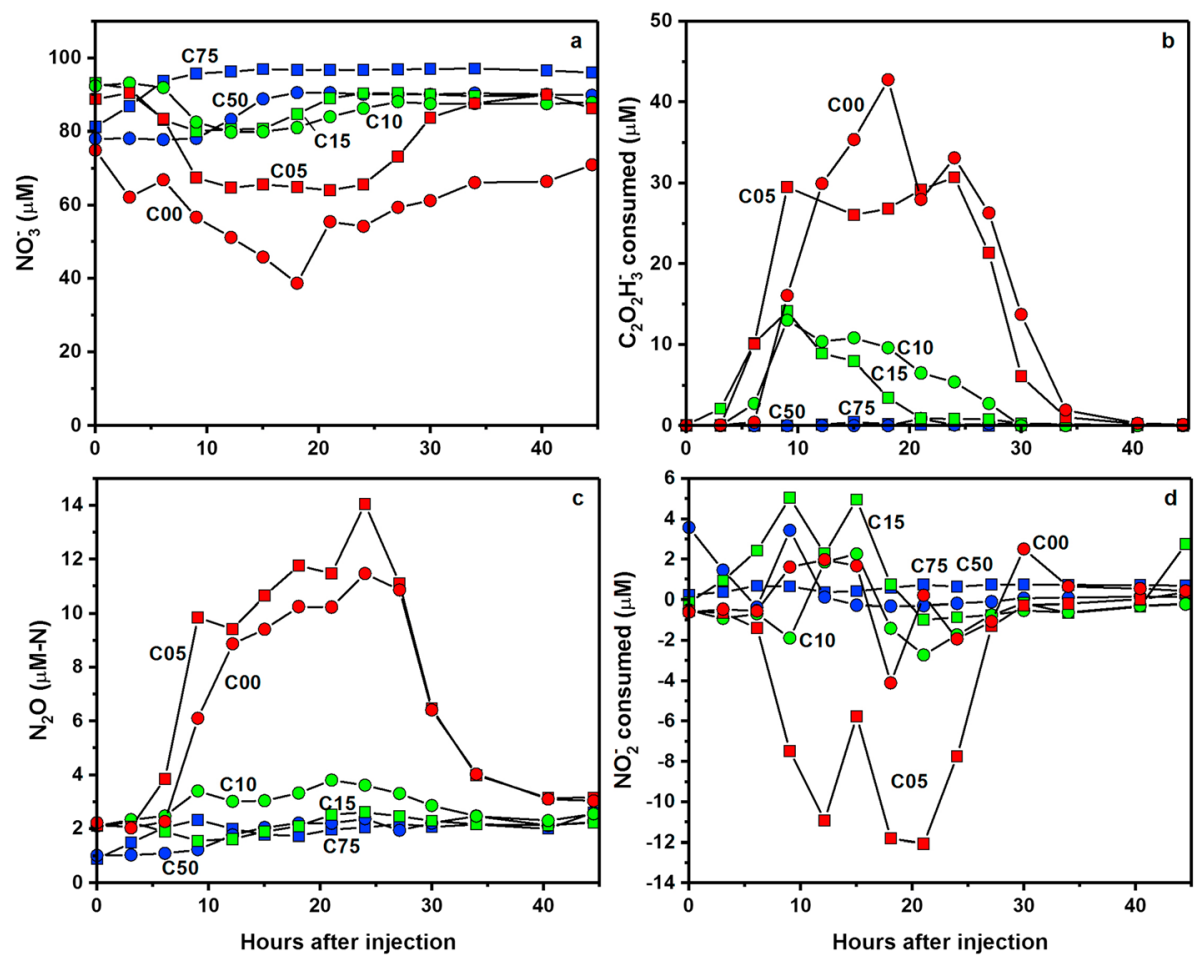

Figure 8. Breakthrough curves for a natural gradient tracer test with nitrite, acetate, and bromide conducted in Ashumet Pond in October 2014 at location C (see map in Figure S2) at indicated depths (cm). (a) Background concentration of nitrate, (b) calculated amount of acetate tracer consumed (relative to bromide), (c) nitrous oxide concentrations, and (d) calculated amount of nitrite tracer consumed (relative to bromide; negative values indicate nitrite production relative to injectate tracer nitrite concentration). Data in Tables S8 and S9.

lakeshore at F744, the vertical geochemical gradients in the contaminant plume are essentially unchanged from the upgradient profiles (Figure $3 b$ ). However, as groundwater moves under the lakeshore and discharges into the lake, the flow lines curve upward and become nearly vertical within $1 \mathrm{~m}$ of the lake bottom. Pore water chemical profiles in the shallow lake sediment where groundwater is discharging are relatively uniform with depth, except for the shallowest samples. For example, at a location about $2 \mathrm{~m}$ from shore in October 2014, concentrations of $\mathrm{O}_{2}, \mathrm{NO}_{3}{ }^{-}$, and $\mathrm{N}_{2} \mathrm{O}$ changed little with upward flow over much of the last meter before discharge (Figure 3c). The change from horizontal flow paths in groundwater to vertical flow paths as discharge occurs into the lake results in a shift from vertical geochemical gradients in the groundwater to horizontal gradients in the lakebed sediment pore water that are largely independent of local biogeochemical processes in the discharge area (compare Figures 3 and 4; McCobb \& LeBlanc, 2011; Stoliker et al., 2016). The vertical chemical gradients close to the lake bottom $(0-10 \mathrm{~cm})$ are attributed to varying combinations of reaction $\left(\mathrm{NO}_{3}{ }^{-}\right.$reduction) and mixing of groundwater and lake water near the interface during sampling.

Groundwater discharge into the lake was not uniform spatially. In the northern portion of Fishermans Cove, groundwater discharge patterns inferred from sediment pore water temperatures in June 2014 showed the expected pattern, where groundwater discharge decreases with distance away from the shore but with localized offshore areas of more intense discharge (Figure 2). In the southern part of Fishermans Cove, the absence of a difference between the lake water and sediment pore water temperatures suggested that there was little discharge only a few meters offshore. In the northern areas the discharge extended nearly $30 \mathrm{~m}$ offshore. Previous studies showed similar patterns and demonstrated that groundwater discharge occurs as far as $100 \mathrm{~m}$ from shore in portions of the Fishermans Cove area (McCobb et al., 2003).

As the lake stage and water table elevation varied with time because of seasonal changes in precipitation and evapotranspiration, the shoreline advanced and retreated, causing shifts in the discharge locations of the geochemical zones observed in upgradient vertical profiles. Although the vertical distributions of $\mathrm{N}$ 
species within the groundwater generally were constant over time, their lateral distributions at the lakebed changed as the lake stage changed. Thus, the area of discharge to the lake of the highest $\mathrm{NO}_{3}{ }^{-}$concentrations advanced and retreated relative to both the shifting shoreline and the fixed lakebed (Figure 4). This discharge zone (i.e., the $\mathrm{NO}_{3}{ }^{-}$plume discharge footprint on the lakebed) was identified by using the grid of pushpoint samplers in the general area of groundwater discharge (Figure 2). The location of the highest $\mathrm{NO}_{3}{ }^{-}$concentration also moved laterally parallel to shore, particularly at the 10-year low lake stage (note the location of the October 2014 transect as compare to the June 2013 transect in Figure 2). Direct measurements of seepage made during each sampling event (Table 1) confirmed the co-occurrence of groundwater discharge and high $\mathrm{NO}_{3}{ }^{-}$concentrations.

\subsection{Nitrogen Cycle Gene Abundance and Sediment Activity Assays}

The changing location of the groundwater $\mathrm{NO}_{3}{ }^{-}$flux into the lake implies that the sediment microbial community and the plant and animal benthic communities at many fixed locations were being subjected to continual changes in geochemical regimes fluxing through the sediments and across the sediment-water interface. Rates of denitrification and $\mathrm{NO}_{3}{ }^{-}$consumption potential were high in all the near-surface sediments receiving groundwater discharge (Figures $6 \mathrm{a}$ and $6 \mathrm{c}$ ). The potential rates for those processes did not appear to be affected by the spatially variable $\mathrm{NO}_{3}{ }^{-}$concentrations in the discharge. However, rates of both processes decreased markedly with depth below the top $0-5-\mathrm{cm}$ interval. Thus, the vertical profile of denitrification potential was similar to profiles observed in lake or marine sediments at other locations (Laverman et al., 2007; Seitzinger, 1988) where diffusive flux dominates solute movement across the sediment-water interface in a downward direction, even though solute delivery at the Ashumet Pond study site was predominantly upward. The relevance of water movement to $\mathrm{N}$ cycling processes within the sediments was not readily apparent based solely on process rate potentials and functional gene quantification. The Ashumet Pond results contrast with studies of subestuarine $\mathrm{NO}_{3}{ }^{-}$discharge in which $\mathrm{NO}_{3}{ }^{-}$removal rates were greater in deeper sediments, with decreasing activity and $\mathrm{NO}_{3}{ }^{-}$concentrations near the surface (Couturier et al., 2017; Kroeger \& Charette, 2008; Slater \& Capone, 1987). Differences in sediment process distribution between freshwater and subestuarine systems result in part from tidal influences and steep salinity gradients along groundwater flow paths in subestuarine systems, neither of which are factors in inland lakes.

Although dissolved $\mathrm{NH}_{4}{ }^{+}$concentrations were near or below detection limits in lakebed pore water within the $\mathrm{NO}_{3}{ }^{-}$discharge zone, both nitrification and anammox potential activities were measurable in microcosms. Net potential nitrification rates were very low in near-surface sediments relative to other $\mathrm{N}$ cycle process rates, in agreement with results reported by Stoliker et al. (2016). Anammox potential rates were higher in deeper sediments than in shallow sediments and even exceeded denitrification potential rates in the deeper sediments farthest from shore (11.2-14.5 m) along the sediment sampling transect. This region of the transect is beyond the farthest migration of the dissolved $\mathrm{O}_{2}$ gradient toward the center of the lake during the study period (see Figure 4) and thus presents a more stable anoxic environment as opposed to near-shore locations, which fluctuate between oxic and anoxic conditions and would therefore tend to favor denitrification over anammox. Anammox activity has been found in this sand and gravel aquifer upgradient of Ashumet Pond (Smith et al., 2015), and its presence has been reported in Ashumet Pond and other freshwater sediments (Penton et al., 2006; Stoliker et al., 2016; Zhou et al., 2014; Zhu et al., 2010). $\mathrm{The}^{\mathrm{NH}_{4}}{ }^{+}$ source for both nitrification and anammox must ultimately be mineralization of organic N, with perhaps some DNRA activity, though the low sediment $\mathrm{C}$ content would not favor DNRA. Slow rates of mineralization to produce $\mathrm{NH}_{4}{ }^{+}$would likely control both nitrification and anammox activity, while lack of $\mathrm{O}_{2}$ in sediment pore water would be an additional factor limiting nitrification at the $\mathrm{NO}_{3}{ }^{-}$discharge zone, where upward advection of anoxic water would greatly exceed downward diffusion of dissolved $\mathrm{O}_{2}$.

Higher abundance of denitrifying communities was measured in the near-surface sediments than in the deeper sediments even though $\mathrm{NO}_{3}{ }^{-}$was continually supplied by groundwater discharge throughout the vertical profile. Among the geochemical parameters examined, Fe, Mn, and S were shown to have significant positive correlations with the abundance of denitrification genes, but not with total sediment $\mathrm{C}$ content. The addition of acetate stimulated both $\mathrm{NO}_{2}{ }^{-}$and $\mathrm{N}_{2} \mathrm{O}$ net production during the in situ tracer tests, but only in the top 5-10 cm, even though a substantial portion of the acetate was consumed below the 5-10 cm interval. Together, these results suggest that heterotrophic denitrification may have been limited to the top $5 \mathrm{~cm}$ 
in the lakebed sediments at the groundwater discharge locations and relatively inactive below that depth interval. As suggested by Burgin and Hamilton (2007), heterotrophic denitrification may have been overemphasized in previous studies as compared to other $\mathrm{NO}_{3}{ }^{-}$reduction pathways, particularly in environments with relatively low degradable $\mathrm{C}$ content, similar to the Fishermans Cove area of Ashumet Pond. The $\mathrm{DOC} / \mathrm{NO}_{3}{ }^{-}$molar ratio in Fishermans Cove pore water from $100 \mathrm{~cm}$ was 1.4 (Figure 3), a value near the stoichiometric threshold limiting heterotrophic denitrifying activity (Taylor \& Townsend, 2010). Rates of $\mathrm{NO}_{3}{ }^{-}$ consumption, which would include $\mathrm{N}_{2} \mathrm{O}$ production by denitrification, $\mathrm{NO}_{3}{ }^{-}$reduction to $\mathrm{NO}_{2}{ }^{-}$, and $\mathrm{NO}_{3}{ }^{-}$ assimilation, were significantly and positively correlated with total sediment $\mathrm{C}$, as well as Fe, Mn, and $\mathrm{S}$ (Table 3). Thus, processes other than heterotrophic denitrification could also have played a role in consuming groundwater $\mathrm{NO}_{3}{ }^{-}$in Fishermans Cove, but only to a limited extent, particularly below the top $5 \mathrm{~cm}$ depth interval.

Abundance of anammox bacteria based on the hzo gene quantification was positively correlated with the anammox rates, which had a negative correlation with both nosZI and nosZII gene abundance (Table 3). No significant difference between the hzo gene abundance in the near-surface and deeper sediments was observed in this study, which differs from the depth profiles of anammox bacterial abundance found in shallow, eutrophic Lake Taihu in China (Qin et al., 2018). This contrast might be the result of hydrologic control on fluctuating $\mathrm{N}$ substrates and dissolved $\mathrm{O}_{2}$ concentrations in Ashumet Pond, preventing proliferation of anammox bacteria, which have characteristically slow growth rates (Oshiki et al., 2016). This is further evidence supporting a preference by anammox bacteria for niches with a steady supply of $\mathrm{N}$ substrates.

Positive correlations between gene abundance and rate measurements support the use of the functional genes to assess both anammox and denitrification activities in the environment. This agrees with other studies that have found a linkage between the structure and function of microbial communities (Graham et al., 2014; Lisa et al., 2015). Transcripts of the functional genes have also been used to identify active members of microbial communities, but correlation between transcripts and rates was rarely observed because of the transient nature of transcripts (Rocca et al., 2015). The results reported here provide additional evidence that functional gene measurements of denitrification and anammox are a useful predictor to assess the fate of $\mathrm{NO}_{3}{ }^{-}$transported by advection to lakes and other ecosystems.

\subsection{In Situ Controls on Nitrite and Nitrate Attenuation}

The distribution and patterns of $\delta^{15} \mathrm{~N}$ and $\delta^{18} \mathrm{O}$ values in groundwater $\mathrm{NO}_{3}{ }^{-}$upgradient of Ashumet Pond indicate that the $\mathrm{NO}_{3}{ }^{-}$being delivered to the lake was isotopically fractionated previously by dissimilatory processes. Both $\mathrm{N}$ and $\mathrm{O}$ were progressively enriched in the heavier isotope $\left({ }^{15} \mathrm{~N}\right.$ and $\left.{ }^{18} \mathrm{O}\right)$ with increasing depth in the contaminated portion of the aquifer (Figure 5). This result is consistent with previous studies that demonstrated that denitrification and anammox were occurring within the contaminant plume (Smith et al., 2004; Smith et al., 2015; Smith, Howes, et al., 1991). Nitrite and $\mathrm{N}_{2} \mathrm{O}$ in the groundwater were associated with the active zone of denitrification, as the individual steps of the denitrification pathway were occurring at different rates and resulting in variable accumulation of the pathway intermediates (Smith et al., 2004). Horizontal variations of $\delta^{15} \mathrm{~N}$ and $\delta^{18} \mathrm{O}$ values of $\mathrm{NO}_{3}{ }^{-}$in sediment pore water at a constant depth of $100 \mathrm{~cm}$ below the lakebed generally were similar to vertical isotopic variations in upgradient groundwater (Figure 5), indicating that they were caused mainly by upgradient $\mathrm{NO}_{3}{ }^{-}$reactions. Relations between $\mathrm{NO}_{3}{ }^{-}$concentrations and isotopic compositions within each of the pore water profiles generally were not consistent with progressive $\mathrm{NO}_{3}{ }^{-}$reduction during upward flow from 100 to $10 \mathrm{~cm}$ beneath the lakebed. Some of those variations likely indicate that upward flow was not exactly vertical, such that the pore water profiles were not exactly aligned with flow. In contrast, at least three out of four profiles exhibited upward increases in $\delta^{15} \mathrm{~N}$ and $\delta^{18} \mathrm{O}$ values associated with decreases in $\mathrm{NO}_{3}{ }^{-}$concentration in the upper $10 \mathrm{~cm}$ that were qualitatively consistent with relatively high rates of $\mathrm{NO}_{3}{ }^{-}$reduction near the sedimentwater interface.

The $\mathrm{NO}_{2}{ }^{-}$natural-gradient tracer tests demonstrated that in situ $\mathrm{NO}_{2}{ }^{-}$consumption rates in the lakebed sediments were very low in the 75 to $15 \mathrm{~cm}$ interval and increased only after the tracer $\mathrm{NO}_{2}{ }^{-}$was transported through the more $\mathrm{C}$-rich sediments from $10 \mathrm{~cm}$ to the sediment-water interface. This result is consistent with the $\mathrm{NO}_{3}{ }^{-}$isotope data and with the consumption rates of background $\mathrm{NO}_{3}{ }^{-}$during the second tracer test. Nitrate consumption rates were low in the deeper interval, even when acetate was present, and 


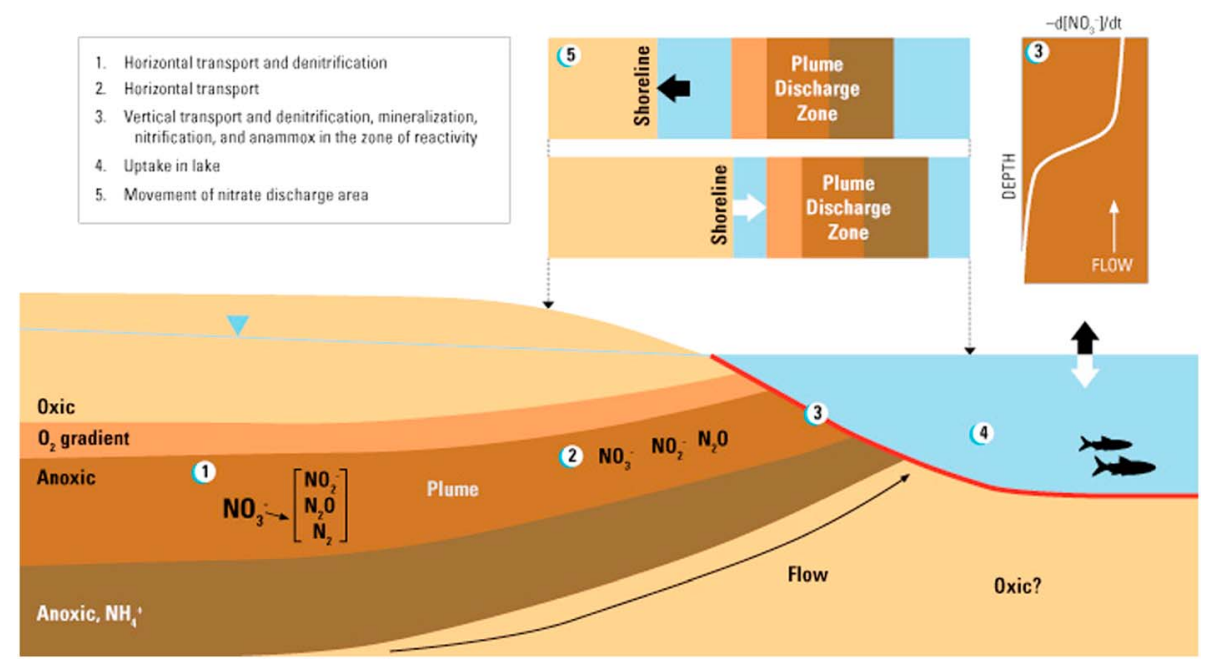

Figure 9. Diagrammatic interpretation of a groundwater contaminant plume discharging into a freshwater lake. (1) Nitrate dissimilatory processes occur upgradient within the suboxic to anoxic portion of the contaminant plume when electron supply is available, producing $\mathrm{N}_{2}$ and intermediate $\mathrm{NO}_{x}$ species. (2) As electron supply is depleted, there is little subsequent reactivity and DIN constituents move downgradient in nearly horizontal flow paths, arriving in the vicinity of the lakebed. (3) Within the lakebed, where more degradable carbon is available, flow paths angle upward, and there is a greater potential for $\mathrm{N}$ cycle redox reactions such as anammox and denitrification to occur. However, the zone of reactivity is relatively thin (red-shaded area) and transit times, which can be quite short, dictate the extent to which biogeochemical processes transform or remove DIN species, resulting in (4) delivery and uptake of DIN in the water column of the lake. (5) Additionally, the zone of reactivity moves spatially with time as the plume discharge location changes with changing lake and water table levels, which rise (black arrows) and fall (white arrows) as precipitation and evapotranspiration vary seasonally and over long periods, subjecting the microbial populations at any fixed location within the lakebed to continually changing geochemical regimes.

substantially higher in the shallow interval. However, the pore water residence time in the top $10 \mathrm{~cm}$ was only slightly longer than $2 \mathrm{hr}$. Thus, the amount of $\mathrm{NO}_{3}{ }^{-}$removed prior to discharge to the lake was no more than $30-40 \%$ of the incoming pore water $\mathrm{NO}_{3}{ }^{-}$concentration in the near-surface sediment, even when acetate was present. Although the microbial community was functionally primed and capable of reducing substantial amounts of $\mathrm{NO}_{3}{ }^{-}$prior to discharge, electron donor limitation coupled with relatively rapid transit rates through the active zone precluded substantial $\mathrm{NO}_{3}{ }^{-}$removal from occurring. If anything, the tracer tests and the pore water profiles suggest that the shallow zone of active $\mathrm{N}$ cycling was contributing additional $\mathrm{NO}_{2}{ }^{-}$and $\mathrm{N}_{2} \mathrm{O}$ to the pore water just before it was discharging to the lake (Figures 3c and 7c).

Ashumet Pond is typical of many pristine and mesotrophic lakes, including the Laurentian Great Lakes; the shallow, nearshore sediments have a relatively low $\mathrm{C}$ content as compared to wetlands or other eutrophic bodies of water. Groundwater discharge to these low $\mathrm{C}$ systems can potentially serve as a substantial nutrient source, contributing to harmful algal blooms, and a source of other toxic contaminants (Lee et al., 2014; Robinson, 2015; Roy \& Malenica, 2013). However, this obviously depends on the removal rates and transport rates within the lakebed sediments. Literature reports of sediment denitrification rates compiled from 21 lake studies (using various quantification methods) averaged $126 \pm 105 \mu \mathrm{mol} \mathrm{N}$ reduced m${ }^{-2} \mathrm{hr}^{-1}$ (PinaOchoa \& Alvarez-Cobelas, 2006). For comparison, the average microcosm rate for near-surface sediments $(0-5 \mathrm{~cm})$ collected from Ashumet Pond in June 2015 and incubated in the lab was $174 \mu \mathrm{mol} \mathrm{N} \mathrm{m}^{-2} \mathrm{hr}^{-1}$ (Figure 6; conversion: $1 \mathrm{~g}$ dry sediment $=0.525 \mathrm{ml}$ wet sediment). Tracer-test rate estimates, which are approximations of bulk in situ $\mathrm{NO}_{3}{ }^{-}$reduction rates, ranged from 22.4 (as $\mathrm{N}_{2} \mathrm{O}$ produced) to 47.6 (as $\mathrm{NO}_{2}{ }^{-}$loss) $\mu \mathrm{mol} \mathrm{N} \mathrm{m}{ }^{-2} \mathrm{hr}^{-1}$ (calculated for a $10 \mathrm{~cm}$ depth interval). These rates are about 4 to 8 times lower than the microcosm potential rate estimates, though it must be noted that the electron balance differs between the various methods (e.g., $\mathrm{NO}_{3}{ }^{-}$reduction to $\mathrm{N}_{2} \mathrm{O}$ for the $\mathrm{C}_{2} \mathrm{H}_{2}$ block versus $\mathrm{N}_{2}$ production using ${ }^{15} \mathrm{~N}_{-\mathrm{NO}_{3}}{ }^{-}$). The difference between the $\mathrm{NO}_{2}{ }^{-}$consumed and $\mathrm{N}_{2} \mathrm{O}$ produced must be due to some combination of processes that could include $\mathrm{N}_{2} \mathrm{O}$ reduction to $\mathrm{N}_{2}$ via canonical denitrification, $\mathrm{NO}_{2}{ }^{-}$reduction directly to $\mathrm{N}_{2}$ coupled with methane oxidation (Ettwig et al., 2010), abiotic $\mathrm{NO}_{2}{ }^{-}$conversion to $\mathrm{N}_{2}$ 
mediated by nitrosation (Phillips et al., 2016), anoxic $\mathrm{NO}_{2}{ }^{-}$oxidation to $\mathrm{NO}_{3}{ }^{-}$by anammox in the deeper sediments (Kartal et al., 2012), and nitrification in the surface sediments, where $\mathrm{O}_{2}$ is present in low concentration. Additional tracer tests with ${ }^{15} \mathrm{~N}$-labeled substrates would be needed to discern the extent to which these other processes are occurring.

Many factors have been shown to control sediment $\mathrm{NO}_{3}{ }^{-}$reduction rates, including $\mathrm{NO}_{3}{ }^{-}, \mathrm{C}$, and $\mathrm{O}_{2}$ concentrations, and gene abundance (e.g., see Lisa et al., 2015; Pina-Ochoa \& Alvarez-Cobelas, 2006). While the dynamics of water movement have been recognized as a controlling factor for $\mathrm{N}$ attenuation in hyporheic zones of streams and rivers (Böhlke et al., 2009; Grant et al., 2018; Harvey et al., 2013; Seitzinger et al., 2006; Zarnetske et al., 2012) and subterranean estuaries (Kroeger \& Charette, 2008; Michael et al., 2005; Spiteri et al., 2008; Ueda et al., 2003), this lakebed study clearly emphasizes the importance of hydrologic transport and the associated seasonal variability on the spatial pattern of groundwater $\mathrm{N}$ delivery to lakes and the limiting effect of electron donor availability along upgradient groundwater flow paths.

\section{Conclusions}

The fate of groundwater $\mathrm{NO}_{3}{ }^{-}$and other contaminants discharging into a lake depends on coupling between hydrologic and geochemical processes within, and upgradient of, the discharge area, as depicted in Figure 9. Where a groundwater contaminant plume discharges into a lake, the discharge location (or contaminant footprint on the lakebed) is controlled by water table and lake-stage fluctuations and moves accordingly with the shifting hydraulic gradient and shoreline location. Removal rates of $\mathrm{NO}_{3}{ }^{-}$, and potentially other contaminants, in the discharging groundwater can be relatively high on a volumetric basis as the groundwater nears the groundwater-lake interface owing to microbial activity stimulated by lake-derived organic $C$, but short residence times can limit the amount of $\mathrm{NO}_{3}{ }^{-}$removed before discharge, resulting in relatively low removal rates on an areal basis. This suggests that under circumstances similar to this study, upgradient natural attenuation processes could be more important for mitigating the impact of $\mathrm{N}$ compounds on downgradient lakes than those at the groundwater-lake interface. However, dissimilatory nitrogen removal processes near the ends of groundwater discharge flow paths in nearshore sediments could have a secondary indirect impact on lake water geochemistry by increasing the fluxes of $\mathrm{N}_{2} \mathrm{O}$ and $\mathrm{NO}_{2}{ }^{-}$across the sediment-water interface where $\mathrm{NO}_{3}^{-}$was discharging to the lake.

The shallow sediment microbial populations in this system experience continual shifting of geochemical redox conditions to which they must frequently adapt. The predominance of hydrologic transport over nitrogen removal mechanisms in systems similar to Ashumet Pond, which likely also applies to other contaminant transport processes, exposes benthic communities within the lake at groundwater discharge locations to essentially the whole range of groundwater contaminants and redox conditions that might be arriving at the groundwater-lake interface. The changing spatial pattern of the contaminated groundwater discharge was related to local hydrologic conditions, as well as inherited upgradient contaminant plume features, which caused local variations in contaminant exposure in the lakebed and thus complicates the assessment of natural attenuation.

\section{References}

Aiken, G. R. (1992). Chloride interference in the analysis of dissolved organic carbon by the wet oxidation method. Environmental Science and Technology, 26(12), 2435-2439. https://doi.org/10.1021/es00036a015

Barbaro, J. R., Walter, D. A., \& LeBlanc, D. R. (2013). Transport of nitrogen in a treated-wastewater plume to coastal discharge areas, Ashumet Valley, Cape Cod, Massachusetts, U. S. Geological Survery Scientific Investigations Report, 37 pp, http://pubs.usgs.gov/sir/ 2013/5061/

Barber, L. B., Thurman, E. M., \& Runnells, D. D. (1992). Geochemical heterogeneity in a sand and gravel aquifer: Effect of sediment mineralogy and particle size on the sorption of chlorobenzenes. Journal of Contaminant Hydrology, 9(1-2), 35-54. https://doi.org/ 10.1016/0169-7722(92)90049-K

Böhlke, J. K., Antweiler, R. C., Harvey, J. W., Laursen, A. E., Smith, L. K., Smith, R. L., \& Voytek, M. A. (2009). Multi-scale measurements and modeling of denitrification in streams with varying flow and nitrate concentrations in the upper Mississippi River basin, USA. Biogeochemistry, 93(1-2), 117-141. https://doi.org/10.1007/s10533-008-9282-8

Böhlke, J. K., Mroczkowski, S. J., \& Coplen, T. B. (2003). Oxygen isotopes in nitrate: New reference materials for ${ }^{18} \mathrm{O}:{ }^{17} \mathrm{O}:{ }^{16} \mathrm{O}$ measurements and observations on nitrate-water equilibration. Rapid Communications in Mass Spectrometry, 17(16), 1835-1846. https://doi.org/ $10.1002 / \mathrm{rcm} .1123$

Böhlke, J. K., Smith, R. L., \& Hannon, J. E. (2007). Isotopic analysis of $\mathrm{N}$ and $\mathrm{O}$ in nitrite and nitrate by sequential selective bacterial reduction to $\mathrm{N}_{2} \mathrm{O}$. Analytical Chemistry, 79(15), 5888-5895. https://doi.org/10.1021/ac070176k 
Böhlke, J. K., Smith, R. L., \& Miller, D. N. (2006). Ammonium transport and reaction in contaminated groundwater: Application of isotope tracers and isotope fractionation studies. Water Resources Research, 42, W05411. https://doi.org/10.1029/2005WR004349

Böttcher, J., Strebel, O., Voerkelius, S., \& Schmidt, H. L. (1990). Using isotope fractionation of nitrate-nitrogen and nitrate-oxygen for evaluation of microbial denitrification in a sandy aquifer. Journal of Hydrology, 114(3-4), 413-424. https://doi.org/10.1016/00221694(90)90068-9

Brunner, B., Contreras, S., Lehman, M. F., Matantseva, O., Rollog, M., Kalvelage, T., et al. (2014). Nitrogen isotope effects induced by anammox bacteria. Proceedings of the National Academy of Sciences of the United States of America, 110(47), 18994-18999.

Buchwald, C., \& Casciotti, K. L. (2013). Isotopic ratios of nitrite as tracers of the sources and age of oceanic nitrite. Nature Geoscience, 6(4), 308-313. https://doi.org/10.1038/ngeo1745

Burgin, A. J., \& Hamilton, S. K. (2007). Have we overemphasized the role of denitrification in aquatic ecosystems? A review of nitrate removal pathways. Frontiers in Ecology and the Environment, 5(2), 89-96. https://doi.org/10.1890/1540-9295(2007)5[89:HWOTRO]2.0. $\mathrm{CO} ; 2$

Casciotti, K. L. (2016). Nitrogen and oxygen isotopic studies of the marine nitrogen cycle. Annual Review of Marine Science, 8(1), 379-407. https://doi.org/10.1146/annurev-marine-010213-135052

Casciotti, K. L., Böhlke, J. K., McIlvin, M. R., Mroczkowski, S. J., \& Hannon, J. E. (2007). Oxygen isotopes in nitrite: Analysis, calibration, and equilibration. Analytical Chemistry, 79(6), 2427-2436. https://doi.org/10.1021/ac061598h

Casciotti, K. L., Sigman, D. M., Galanter Hastings, M., Böhlke, J. K., \& Hilkert, A. (2002). Measurement of the oxygen isotopic composition of nitrate in seawater and freshwater using the denitrifier method. Analytical Chemistry, 74(19), 4905-4912. https://doi.org/10.1021/ ac020113w

Couturier, M., Tommi-Morin, G., Sirois, M., Rao, A., Nozais, C., \& Chaillou, G. (2017). Nitrogen transformations along a shallow subterranean estuary. Biogeosciences, 14(13), 3321-3336. https://doi.org/10.5194/bg-14-3321-2017

Damashek, J., \& Francis, C. A. (2018). Microbial nitrogen cycling in estuaries: From genes to ecosystem processes. Estuaries and Coasts, 41(3), 626-660. https://doi.org/10.1007/s12237-017-0306-2

Duff, J. H., Tesoriero, A. J., Richardson, W. B., Strauss, E. A., \& Munn, M. D. (2008). Whole-stream response to nitrate loading in three streams draining agricultural landscapes. Journal of Environmental Quality, 37(3), 1133-1144. https://doi.org/10.2134/jeq2007.0187

Ettwig, K. F., Butler, M. K., Le Paslier, D., Pelletier, E., Mangenot, S., Kuypers, M. M. M., et al. (2010). Nitrite-driven anaerobic methane oxidation by oxygenic bacteria. Nature, 464(7288), 543-548. https://doi.org/10.1038/nature08883

Garabedian, S. P., LeBlanc, D. R., Gelhar, L. W., \& Celia, M. A. (1991). Large-scale natural gradient tracer test in sand and gravel, Cape Cod, Massachusetts: 2. Analysis of spatial moments for a nonreactive tracer. Water Resources Research, 27(5), 911-924. https://doi.org/ 10.1029/91WR00242

Graham, E. B., Wieder, W. R., Leff, J. W., Weintraub, S. R., Townsend, A. R., Cleveland, C. C., et al. (2014). Do we need to understand microbial communities to predict ecosystem function? A comparison of statistical models of nitrogen cycling processes. Soil Biology and Biochemistry, 68, 279-282. https://doi.org/10.1016/j.soilbio.2013.08.023

Granger, J., \& Sigman, D. M. (2009). Removal of nitrite with sulfamic acid for nitrate N and O isotope analysis with the denitrifier method. Rapid Communications in Mass Spectrometry, 23(23), 3753-3762. https://doi.org/10.1002/rcm.4307

Granger, J., Sigman, D. M., Lehmann, M. F., \& Tortell, P. D. (2008). Nitrogen and oxygen isotope fractionation during dissimilatory nitrate reduction by denitrifying bacteria. Limnology and Oceanography, 53(6), 2533-2545. https://doi.org/10.4319/lo.2008.53.6.2533

Granger, J., \& Wankel, S. D. (2016). Isotopic overprinting of nitrification on denitrification as a ubiquitous and unifying feature of environmental nitrogen cycling. Proceedings of the National Academy of Sciences of the United States of America, 113(42), E6391-E6400. https://doi.org/10.1073/pnas.1601383113

Grant, S. B., Azizian, M., Cook, P., Boano, F., \& Rippy, M. A. (2018). Factoring stream turbulence into global assessments of nitrogen pollution. Science, 359(6381), 1266-1269. https://doi.org/10.1126/science.aap8074

Groffman, P. M., Dorsey, A. M., \& Mayer, P. M. (2005). N processing within geomorphic structures in urban streams. Journal of the North American Benthological Society, 24(3), 613-625. https://doi.org/10.1899/04-026.1

Hampel, J. J., McCarthy, M. J., Gardner, W. S., Zhang, L., Xu, H., Zhu, G., \& Newell, S. E. (2018). Nitrification and ammonium dynamics in Taihu Lake, China: Seasonal competition for ammonium between nitrifiers and cyanobacteria. Biogeosciences, 15(3), 733-748. https:// doi.org/10.5194/bg-15-733-2018

Harvey, J. W., Böhlke, J. K., Voytek, M. A., Scott, D., \& Tobias, C. R. (2013). Hyporheic zone denitrification: Controls on effective reaction depth and contribution to whole-stream mass balance. Water Resources Research, 49, 6298-6316. https://doi.org/10.1002/wrcr.20492

Harvey, R. W., Metge, D. W., LeBlanc, D. R., Underwood, J., Aiken, G. R., Butler, K., et al. (2015). Importance of the colmation layer in the transport and removal of cyanobacteria, viruses, and dissolved organic carbon during natural lake-bank filtration. Journal of Environmental Quality, 44(5), 1413-1423. https://doi.org/10.2134/jeq2015.03.0151

Hess, K. M., Wolf, S. H., \& Celia, M. A. (1992). Large-scale natural gradient tracer test in sand and gravel, Cape Cod, Massachusetts: 3. Hydraulic conductivity variability and calculated macrodispersivities. Water Resources Research, 28(8), 2011-2027. https://doi.org/ 10.1029/92WR00668

Hinkle, S. R., Duff, J. H., Triska, F. J., Laenen, A., Gates, E. B., Bencala, K. E., et al. (2001). Linking hyporheic flow and nitrogen cycling near the Willamette River-A large river in Oregon, USA. Journal of Hydrology, 244(3-4), 157-180. https://doi.org/10.1016/S00221694(01)00335-3

Jones, C. M., Graf, D. R., Bru, D., Philippot, L., \& Hallin, S. (2013). The unaccounted yet abundant nitrous oxide-reducing microbial community: A potential nitrous oxide sink. ISME Journal, 7(2), 417-426. https://doi.org/10.1038/ismej.2012.125

Kartal, B., van Niftrik, L. A., Keltjens, J. T., Op den Camp, H. J. M., \& Jetten, M. S. M. (2012). Anammox-Growth physiology, cell biology, and metabolism. Advances in Microbial Physiology, 60, 211-262. https://doi.org/10.1016/B978-0-12-398264-3.00003-6

Keery, J., Binley, A., Crook, N., \& Smith, J. W. N. (2007). Temporal and spatial variability of groundwater-surface water fluxes: Development and application of an analytical method using temperature time series. Journal of Hydrology, 336(1-2), 1-16. https://doi. org/10.1016/j.jhydrol.2006.12.003

Kent, D. B., Davis, J. A., Anderson, L. C. D., Rea, B. A., \& Waite, T. D. (1994). Transport of chromium and selenium in the suboxic zone of a shallow aquifer: Influence of redox and adsorption reactions. Water Resources Research, 30(4), 1099-1114. https://doi.org/10.1029/ 93WR03244

Kent, D. B., \& Fox, P. M. (2004). The influence of groundwater chemistry on arsenic concentrations and speciation in a quartz sand and gravel aquifer. Geochemical Transactions, 5(1), 1-12. https://doi.org/10.1186/1467-4866-5-1

Kidmose, J., Engesgaard, P., Ommen, D. A., Nilsson, B., Flindt, M. R., \& Andersen, F. O. (2015). The role of groundwater for lake-water quality and quantification of N seepage. Groundwater, 53(5), 709-721. https://doi.org/10.1111/gwat.12281 
Klueglein, N., \& Kappler, A. (2013). Abiotic oxidation of Fe (II) by reactive nitrogen species in cultures of the nitrate-reducing Fe (II) oxidizer Acidovorax sp. BoFeN1-Questioning the existence of enzymatic Fe (II) oxidation. Geobiology, 11(2), 180-190. https://doi.org/ 10.1111/gbi.12019

Klueglein, N., Zeitvogel, F., Stierhof, Y.-D., Floetenmeyer, M., Konhauser, K. O., Kappler, A., \& Obst, M. (2014). Potential role of nitrite for abiotic Fe (II) oxidation and cell encrustation during nitrate reduction by denitrifying bacteria. Applied and Environmental Microbiology, 80(3), 1051-1061. https://doi.org/10.1128/AEM.03277-13

Kroeger, K. D., \& Charette, M. A. (2008). Nitrogen biogeochemistry of submarine groundwater discharge. Limnology and Oceanography, 53(3), 1025-1039. https://doi.org/10.4319/lo.2008.53.3.1025

Laverman, A. M., Meile, C., Van Cappellen, P., \& Wieringa, E. B. A. (2007). Vertical distribution of denitrification in an estuarine sediment: Integrating sediment flowthrough reactor experiments and microprofiling via reactive transport modeling. Applied and Environmental Microbiology, 73(1), 40-47. https://doi.org/10.1128/AEM.01442-06

LeBlanc, D. R. (1984). Sewage plume in a sand and gravel aquifer, Cape Cod, Massachusetts, U. S. Geological Survey Water Supply Paper, 2218, 28 pp, https://pubs.usgs.gov/wsp/wsp2218/.

LeBlanc, D. R., Garabedian, S. P., Hess, K. M., Gelhar, L. W., Quadri, R. D., Stollenwerk, K. G., \& Wood, W. W. (1991). Large-scale natural gradient tracer test in sand and gravel, Cape Cod, Massachusetts: 1. Experimental design and observed tracer movement. Water Resources Research, 27(5), 895-910. https://doi.org/10.1029/91WR00241

Lee, J., Robinson, C., \& Couture, R. M. (2014). Effect of groundwater-lake interactions on arsenic enrichment in freshwater beach aquifers. Environmental Science and Technology, 48(17), 10,174-10,181. https://doi.org/10.1021/es5020136

Lewandowski, J., Meinikmann, K., Nützmann, G., \& Rosenberry, D. O. (2015). Groundwater-The disregarded component in lake water and nutrient budgets: 2. Effects of groundwater on nutrients. Hydrological Processes, 29(13), 2922-2955. https://doi.org/10.1002/ hyp.10384

Li, Y., Wang, S., Zhang, W., Yuan, J., \& Xu, C. (2017). Potential drivers of the level and distribution of nitrogen in the hyporheic zone of Lake Taihu, China. Water, 9(7). https://doi.org/10.3390/w9070544

Lisa, J. A., Song, B., Tobias, C. R., \& Hines, D. E. (2015). Genetic and biogeochemical investigation of sedimentary nitrogen cycling communities responding to tidal and seasonal dynamics in Cape Fear River Estuary. Estuarine, Coastal and Shelf Science, 167, A313-A323. https://doi.org/10.1016/j.ecss.2015.09.008

McBride, M. S., \& Pfannkuch, H. O. (1975). The distribution of seepage within lake beds. U. S. Geological Survey Journal of Research, 3, 505-512.

McCobb, T. D., Briggs, M. A., LeBlanc, D. R., Day-Lewis, F. D., \& Johnson, C. D. (2018). Evaluating long-term patterns of decreasing groundwater discharge through a lake-bottom permeable reactive barrier. Journal of Environmental Management, 220, 233-245. https:// doi.org/10.1016/j.jenvman.2018.02.083

McCobb, T. D., \& LeBlanc, D. R. (2011). Water-quality data from shallow pond-bottom groundwater in the Fishermans Cove area of Ashumet Pond, Cape Cod, Massachusetts, 2001-2010, U. S. Geological Survey Data Series, 588, 13 pp, https://pubs.usgs.gov/ds/588.

McCobb, T. D., LeBlanc, D. R., Walter, D. A., Hess, K. M., Kent, D. B., and Smith, R. L. (2003). Phosphorus in a ground-water contaminant plume discharging to Ashumet Pond, Cape Cod, Massachusetts 1999, U. S. Geological Survey Water-Resources Investigations Report, 024306, 69 pp, https://pubs.usgs.gov/wri/wri024306/pdfs/wrir024306.pdf.

Michael, H. A., Mulligan, A. E., \& Harvey, C. F. (2005). Seasonal oscillations in water exchange between aquifers and the coastal ocean. Nature, 436(7054), 1145-1148. https://doi.org/10.1038/nature03935

Miller, D. N., \& Smith, R. L. (2009). Microbial characterization of nitrification in a shallow, nitrogen-contaminated aquifer, Cape Cod, Massachusetts and detection of a novel cluster associated with nitrifying Betaproteobacteria. Journal of Contaminant Hydrology, 103(3-4), 182-193. https://doi.org/10.1016/j.jconhyd.2008.10.011

Mulholland, P. J., Hall, R. O. Jr., Sobota, D. J., Dodds, W. K., Findlay, S. E. G., Grimm, N. B., et al. (2009). Nitrate removal in stream ecosystems measured by $15 \mathrm{~N}$ addition experiments: Denitrification. Limnology and Oceanography, 54(3), 666-680. https://doi.org/10.4319/ lo.2009.54.3.0666

Nakayama, T., \& Watanabe, M. (2008). Missing role of groundwater in water and nutrient cycles in the shallow eutrophic lake Kasumigaura, Japan. Hydrological Processes, 22(8), 1150-1172. https://doi.org/10.1002/hyp.6684

Oshiki, M., Satoh, H., \& Okabe, S. (2016). Ecology and physiology of anaerobic ammonium oxidizing bacteria. Environmental Microbiology, 18(9), 2784-2796. https://doi.org/10.1111/1462-2920.13134

Penton, C. R., Devol, A. H., \& Tiedje, J. M. (2006). Molecular evidence for the broad distribution of anaerobic ammonium-oxidizing bacteria in freshwater and marine sediments. Applied and Environmental Microbiology, 72(10), 6829-6832. https://doi.org/10.1128/ AEM.01254-06

Peterson, B. J., Wolheim, W. M., Mulholland, P. J., Webster, J. R., Meyer, J. L., Tank, J. L., et al. (2001). Control of nitrogen export from watersheds by headwater streams. Science, 292(5514), 86-90. https://doi.org/10.1126/science.1056874

Pfannkuch, H. O., \& Winter, T. C. (1984). Effect of anisotropy and groundwater system geometry on seepage through lakebeds. Journal of Hydrology, 75(1-4), 213-237. https://doi.org/10.1016/0022-1694(84)90051-9

Phillips, R. L., Song, B., McMillan, A. M., Grelet, G., Weir, B. S., Palmada, T., \& Tobias, C. (2016). Chemical formation of hybrid di-nitrogen calls fungal codenitrification into question. Scientific Reports, 6(1), 39077. https://doi.org/10.1038/srep39077

Pina-Ochoa, E., \& Alvarez-Cobelas, M. (2006). Denitrification in aquatic environments: A cross-system analysis. Biogeochemistry, 81(1), 111-130. https://doi.org/10.1007/s10533-006-9033-7

Qin, H., Han, C., Jin, Z., Wu, L., Deng, H., Zhu, G., \& Zhong, W. (2018). Vertical distribution and community composition of anammox bacteria in sediments of a eutrophic shallow lake. Journal of Applied Microbiology, 125(1), 121-132. https://doi.org/10.1111/ jam.13758

Repert, D. A., Barber, L. B., Hess, K. M., Keefe, S. H., Kent, D. B., LeBlanc, D. R., \& Smith, R. L. (2006). Long-term natural attenuation of carbon and nitrogen within a groundwater plume after removal of the treated wastewater source. Environmental Science and Technology, 40(4), 1154-1162. https://doi.org/10.1021/es051442j

Repert, D. A., Underwood, J. C., Smith, R. L., \& Song, B. (2014). Seasonal nitrogen cycling processes and relationship to microbial community structure in bed sediments from the Yukon River at Pilot Station. Journal of Geophysical Research: Biogeosciences, 119, 2328-2344. https://doi.org/10.1002/2014JG002707

Rissanen, A. J., Tiirola, M., Hietanen, S., \& Ojala, A. (2013). Interlake variation and environmental controls of denitrification across different geographic scales. Aquatic Microbial Ecology, 69(1), 1-16. https://doi.org/10.3354/ame01619

Robinson, C. (2015). Review on groundwater as a source of nutrients to the Great Lakes and their tributaries. Journal of Great Lakes Research, 41(4), 941-950. https://doi.org/10.1016/j.jglr.2015.08.001 
Rocca, J. D., Hall, E. K., Lennon, J. T., Evans, S. E., Waldrop, M. P., Cotner, J. B., et al. (2015). Relationships between protein-encoding gene abundance and corresponding process are commonly assumed yet rarely observed. ISME Journal, 9(8), 1693-1699. https://doi.org/ 10.1038/ismej.2014.252

Rosenberry, D. O., \& LaBaugh, J. W. (2008). Field techniques for estimating water fluxes between surface water and ground water, $U$. $S$. Geological Survey Techniques and Methods, 4-D2, 128 pp, https://pubs.er.usgs.gov/publication/tm4D2.

Rosenberry, D. O., \& Menheer, M. A. (2006). A system for calibrating seepage meters used to measure flow between ground water and surface water, U. S. Geological Survey Scientific Investigations Report, 2006-5053, 21 pp, https://pubs.er.usgs.gov/publication/ $\operatorname{sir} 20065053$

Rosenberry, D. O., Sheibley, R. W., Cox, S. E., Simonds, F. W., \& Naftz, D. L. (2013). Temporal variability of exchange between groundwater and surface water based on high-frequency direct measurements of seepage at the sediment-water interface. Water Resources Research, 49, 2975-2986. https://doi.org/10.1002/wrcr.20198

Rosenberry, D. O., Striegl, R. G., \& Hudson, D. C. (2000). Plants as indicators of focused ground water discharge to a northern Minnesota lake. Groundwater, 38(2), 296-303. https://doi.org/10.1111/j.1745-6584.2000.tb00340.x

Roy, J., \& Malenica, A. (2013). Nutrients and toxic contaminants in shallow groundwater along Lake Simcoe urban shorelines. Inland Waters, 3(2), 125-138. https://doi.org/10.5268/iw-3.2.521

Rysgaard, S., Risgaard-Petersen, N., Nielsen, L. P., \& Revsbech, N. P. (1993). Nitrification and denitrification in lake and estuarine sediments measured by the ${ }^{15} \mathrm{~N}$ dilution technique and isotope pairing. Applied and Environmental Microbiology, 59, $2093-2098$.

Salk, K. R., Bullerjahn, G. S., McKay, R. M. L., Chaffin, J. D., \& Ostrom, N. E. (2018). Nitrogen cycling in Sandusky Bay, Lake Erie: Oscillations between strong and weak export and implications for harmful algal blooms. Biogeosciences, 15(9), 2891-2907. https://doi. org/10.5194/bg-15-2891-2018

Savoie, J. G., \& LeBlanc, D. R. (1998). Water-quality data and methods of analysis for samples collected near a plume of sewagecontaminated ground water, Ashumet Valley, Cape Cod, Massachusetts, 1993-94, U. S. Geological Survey Water-Resources Investigation Report, 97-4269, 208 pp, https://pubs.usgs.gov/wri/wri974269/.

Savoie, J. G., Smith, R. L., Kent, D. B., Hess, K. M., LeBlanc, D. R., \& Barber, L. B. (2006). Ground-water quality data for a treated wastewater plume undergoing natural restoration, Ashumet Valley, Cape Cod Massachusetts, 1994-2004, U. S. Geological Survey Data Series, 198, 339 pp, https://pubs.usgs.gov/ds/2006/198.

Seitzinger, S., Harrison, J. A., Böhlke, J. K., Bouwman, A. F., Lowrance, R. R., Peterson, B., et al. (2006). Denitrification across landscapes and waterscapes: A synthesis. Ecological Applications, 16(6), 2064-2090. https://doi.org/10.1890/1051-0761(2006)016[2064: DALAWA]2.0.CO;2

Seitzinger, S. P. (1988). Denitrification in freshwater and coastal marine ecosystems: Ecological and geochemical significance. Limnology and Oceanography, 33, 702-724.

Slater, J. M., \& Capone, D. G. (1987). Denitrification in aquifer soil and nearshore marine sediments influenced by groundwater nitrate. Applied and Environmental Microbiology, 53(6), 1292-1297.

Smith, R. L., Böhlke, J. K., Garabedian, S. P., Revesz, K. M., \& Yoshinari, T. (2004). Assessing denitrification in groundwater using natural gradient tracer tests with ${ }^{15} \mathrm{~N}$ : In situ measurement of a sequential multistep reaction. Water Resources Research, 40, W07101. https://doi. org/10.1029/2003WR002919

Smith, R. L., Böhlke, J. K., Song, B., \& Tobias, C. R. (2015). Role of anaerobic ammonium oxidation (anammox) in nitrogen removal from a freshwater aquifer. Environmental Science and Technology, 49(20), 12,169-12,177. https://doi.org/10.1021/acs.est.5b02488

Smith, R. L., \& Duff, J. H. (1988). Denitrification in a sand and gravel aquifer. Applied and Environmental Microbiology, 54(5), 1071-1078.

Smith, R. L., \& Harris, S. H. (2007). Determining the terminal electron-accepting reaction in the saturated subsurface. In C. J. Hurst, R. L. Crawford, J. L. Garland, D. A. Lipson, A. L. Mills, \& L. D. Stetzenbach (Eds.), Manual of Environmental Microbiology (pp. 860-871). Washington, D.C.: ASM Press.

Smith, R. L., Harvey, R. W., \& LeBlanc, D. R. (1991). Importance of closely spaced vertical sampling in delineating chemical and microbiological gradients in groundwater studies. Journal of Contaminant Hydrology, 7(3), 285-300. https://doi.org/10.1016/01697722(91)90032-V

Smith, R. L., Howes, B. L., \& Duff, J. H. (1991). Denitrification in nitrate-contaminated groundwater: Occurrence in steep vertical geochemical gradients. Geochimica et Cosmochimica Acta, 55(7), 1815-1825. https://doi.org/10.1016/0016-7037(91)90026-2

Smith, R. L., Kent, D. B., Repert, D. A., \& Böhlke, J. K. (2017). Anoxic nitrate reduction coupled with iron oxidation and attenuation of dissolved arsenic and phosphate in a sand and gravel aquifer. Geochimica et Cosmochimica Acta, 196, 102-120. https://doi.org/10.1016/j. gca.2016.09.025

Smith, R. L., Kent, D. B., Repert, D. A., LeBlanc, D. R., \& Stoliker, D. L. (2018). Natural gradient, lakebed tracer tests using nitrite in a nitrate-contaminated groundwater discharge zone in Ashumet Pond, Massachusetts, U. S. Geological Survey Data Release, doi:https:// doi.org/10.5066/P95E6LQ2

Smith, R. L., Repert, D. A., Stoliker, D. L., Kent, D. B., LeBlanc, D. R., McCobb, T. D., \& Böhlke, J. K. (2018). Seasonal and spatial variation in the location and reactivity of a nitrate-contaminated groundwater discharge zone in Ashumet Pond, Massachusetts., U. S. Geological Survey Data Release, doi:https://doi.org/10.5066/P98KJC3K

Song, B., \& Tobias, C. R. (2011). Molecular and stable isotope methods to detect and measure anaerobic ammonium oxidation (anammox) in aquatic ecosystems. In M. G. Klotz, \& L. Y. Stein (Eds.), Methods in Enzymology: Research on Nitrification and Related Processes. Part B (pp. 63-89). Burlington: Academic Press. https://doi.org/10.1016/B978-0-12-386489-5.00003-8

Spiteri, C., Slomp, C. P., Tuncay, K., \& Meile, C. (2008). Modeling biogeochemical processes in subterranean estuaries: Effect of flow dynamics and redox conditions on submarine groundwater discharge of nutrients. Water Resources Research, 44, W02430. https://doi. org/10.1029/2007WR006071

Stoliker, D. L., Repert, D. A., Smith, R. L., Song, B., LeBlanc, D. R., McCobb, T. D., et al. (2016). Hydrologic controls on nitrogen cycling processes and functional gene abundance in sediments of a groundwater flow-through lake. Environmental Science and Technology, 50(7), 3649-3657. https://doi.org/10.1021/acs.est.5b06155

Taylor, P. G., \& Townsend, A. R. (2010). Stoichiometric control of organic carbon-nitrate relationships from soils to the sea. Nature, 464(7292), 1178-1181. https://doi.org/10.1038/nature08985

Ueda, S., Go, C.-S. U., Suzumura, M., \& Sumi, E. (2003). Denitrification in a seashore sandy deposit influenced by groundwater discharge. Biogeochemistry, 63(2), 187-205. https://doi.org/10.1023/A:1023350227883

Washbourne, I. J., Crenshaw, C. L., \& Baker, M. A. (2011). Dissimilatory nitrate reduction pathways in an oligotrophic aquatic ecosystem: Spatial and temporal trends. Aquatic Microbial Ecology, 65(1), 55-64. https://doi.org/10.3354/ame01538

Wetzel, R. G. (1975). Limnology, (p. 743). Philadelphia: W.B. Saunders, Co. 
Winter, T. C. (1986). Effect of ground-water recharge on configuration of the water table beneath sand dunes and on seepage in lakes in the Sandhills of Nebraska. Journal of Hydrology, 86(3-4), 221-237. https://doi.org/10.1016/0022-1694(86)90166-6

Winter, T. C., Harvey, J. W., Franke, O. L., \& Alley, W. M. (1998). Ground water and surface water: A single resource, U.S. Geological Survey Circular, $1139,79 \mathrm{pp}$.

Yoshinari, T., \& Knowles, R. (1976). Acetylene inhibition of nitrous oxide reduction by denitrifying bacteria. Biochemical and Biophysical Research Communications, 69(3), 705-710. https://doi.org/10.1016/0006-291X(76)90932-3

Zarnetske, J. P., Haggerty, R., Wondzell, S. M., Bokil, V. A., \& Gonzalez-Pinzon, R. (2012). Coupled transport and reaction kinetics control the nitrate source-sink function of hyporheic zones. Water Resources Research, 48, W11508. https://doi.org/10.1029/2012WR011894

Zhou, S., Borjign, S., Riya, S., Terada, A., \& Hosomi, M. (2014). The relationship between anammox and denitrification in the sediment of an inland river. Science of the Total Environment, 490, 1029-1036. https://doi.org/10.1016/j.scitotenv.2014.05.096

Zhu, G., Jetten, M. S. M., Kuschk, P., Ettwig, K. F., \& Yin, C. (2010). Potential roles of anaerobic ammonium and methane oxidation in the nitrogen cycle of wetland ecosystems. Applied Microbiology and Biotechnology, 86(4), 1043-1055. https://doi.org/10.1007/s00253-010$2451-4$ 